\title{
PRACTICAL APPLICATIONS OF ELECTRICAL PRECIPI- TATION AND PROGRESS OF THE RESEARCH CORPORATION
}

\author{
BY LINN BRADLEY
}

Abstract of Paper

The technical and finanical progress made by the Research Corporation since its organization in 1912 is given, and several plants are described. Voltages, electrode spacings, power consumption, etc., are given for several installations. Mention is made of a number of improvements in the electrical apparatus and means for its control. Progress has been made towards standardization of apparatus for this work.

The paper is illustrated with reproductions from photographs of installations in various stages of operation. Curves and charts show the peculiar character of the circuit, the method of obtaining data to be used in designing treaters and of conducting tests. Alternating current of 250,000 volts, has been rectified and used for precipitating particles from gases. Fumes have been separated into fractions by means of temperature control and the electric processes.

A selected bibliography is included. The statement is made that within three years time the original capital of $\$ 10,100$ has been paid back to the stockholders, and that a fund of over $\$ 150$,000 has been accumulated from the corporation's work, to be used for scientific research.

IN CONNECTION with its development and administration of processes for removing from gases finely divided particles suspended therein, the Research Corporation has not only devoted considerable time and effort to consideration of the theories, but also has endeavored to successfully adapt them to a great variety of practical conditions, and to further strengthen and standardize the art. The history and theories of electrical precipitation have been described elsewhere ${ }^{1}$ so it is not necessary to review them in this paper, and, moreover it is considered undesirable to do so because of the wide field to cover in recording the practical and commercial results already achieved.

The article by Dr. F. G. Cottrell, appearing in the annual report of the Secretary of the Smithsonian Institution for the year

Manuscript of this paper was received February 8, 1915.

1. See selected bibliography at end of this paper 
1913 (only recently issued) gives an excellent outline of the work up to the rime when it was submitted to the Public Printer. The present paper aims to broadly cover the work to date, including many things not given in previous articles.

The task of solving the numerous technical problems encountered has been so exacting of time and effort that heretofore it was considered best to refrain from publishing the results of the work and information as to our progress unil the processes had been proved and the organization and the financial position of the corporation were advanced sufficiently to insure its commercial stability. The invitation to present a paper was finally accepted not only because it was believed that sufficient progress of a very definite nature had been made to warrant some statements, but also because it was believed that a report upon the progress and developments would prove to be interesting and valuable to members of this Institute.

The experimental work and the theoretical phases of electrical precipitation are replete with many interesting actual facts,- - and also with apparent facts; and it is these latter which sometimes prove to be dangerous pitfalls. The difference between a successful and an unsuccessful installation often is very litile from an electrical engineer's point of view, because the various other chemical and engineering features often are much more difficult of solution. Partly for these reasons we consider that the knowledge and experience gained through close connection with the wide range of practical work are among our greatest assets. Of course it is to be supposed that improvements and refinements will continue to be made from time to time, but it is hardly to be expected that radical departures from present fundamentals will be made in the near future. The valuable theorics and formulas probably will follow the praclical work, as is usual in this type of work.

Probably a great majority of the Institute's members are aware that high-potential electricity was employed for depositing or condensing particles suspended in gases many years ago, and that the accompanying phenomena could readily be demonstrated in the physicist's laboratory. Nevertheless it is a fact that use of the high-tension electric field for this purpose was not made commercial until in recent years, and that full credit is due Dr. F. G. Cottrell for having made this possible. In this connection the following remark is pertinent to a comparison of theory and industrial application. A well known chemical 
engineer, who invented some valuable processes and has made them commercially successful, has stated that after one has completely solved all of the problems which it is apparently possible to solve in a laboratory, and has obtained comprehensive patents and has thoroughly studied the conceivable theories, and therefore is liable to consider his work almost finished, he is rudely awakened when confronted with the cold, hard fact that fully 90 per cent of the real work remains to be done. It may not be possible to calculate the similar ratio between theory and practise in connection with electrical precipitation, but it is certain that the practical and commercial end has demanded an enormous amount of time and effort. If all the problems were of one type and they required only a knowledge of how to obtain a suitable electric field, the administration and development of the technical work in this particular case would be much. less exacting in time and effort. The variety of problems and conditions, to which requests have been made to apply the processes, has been very extensive as one can readily observe from the information given in a later part of this paper. Nearly every problem which has been investigated by us has required that engineers of our staff not only fully understand our own processes but also be well acquainted with other details of the operations conducted at the plant in question.

The Research Corporation was organized in New York City early in the year 1912, one of its specific duties being to administer the patents assigned gratis to it by Dr. F. G. Cottrell and his associates, E. F. Heller, Edmund O'Neill, and H. E. Miller, these patents being in the field of electrical precipitation. The reader is refersed to Dr. Cottrell's articles for the details of the gift and of the corporation's purposes and aims. ${ }^{2}$ The total capital paid into the treasury was $\$ 10,100$., out of which all expenses for organization, office equipment, salaries, etc., had to be paid until other income was obtained from the work. As the stockholders were prohibited from ever obtaining any profits from their holdings, it was considered unwise to administer the work along lines which might compel the Corporation to request more stubscriptions to ics stock. Also, and for similar reasons, our operations were so conducted that no financial obligations would accrue to either the stockholders or the directors. Therefore, one of the requirements of our early contracts was that the client had to pay all

2. See selected bibliography at end of this paper. 
expenses incident to our work upon his problem, and in addition thereto had to pay to us certain stipulated sums of money for technical services. While this was not the most ideal arrangement, nevertheless it should be realized that the adoption of such policy made it possible to prove and stabilize the work without resorting to the further sale of shares of stock. This latter feature was especially desirable because the founders of the Corporation, and especially Dr. Cottrell, desired to prove and to emphasize the tact that a large sum of?money was entirely unnecessary for starting and proving the work and making the Corporation a financial as well as a technical success. One thought was that the industries benefited by its work should contribute to the support of the altruistic movement. Results have proved the contentions and all the parties who assisted so earnestly and capably, as outlined herein, are entitled to thanks for their generous support.

The technical situation of the electrical precipitation processes in March 1912 was about as follows:

A commercial installation was condensing sulphuric acid mist at the Selby Smelter in California, ${ }^{3}$ this having then been in successful operation for at least two or three years. This installation was designed and superivsed by Dr. F. G. Cottrell assisted by $\mathrm{H}$. A. Burns. It is in steady operation at the present time.

Another installation was made on lead roaster gases at the Selby Smelter, but it was not continued, due primarily to the physical condition of the precipitated material, and because the farmers still complained of the sulphur dioxide which, passing through the treaters as a gas, the processes were not expected to and of course did not remove.

Some experiments ${ }^{4}$ had been made by Dr. Cottrell assisted by Mr. Burns at the Balaklala Smeltẹ in Shasta County, California, and a large installation was subsequently made for treating all the gases passing in the main fluc. This large installation removed from 80 per cent to 90 per cent of all solids, and, had it not been shut down pursuant to a court order obtained by the farmers and likewise based on the sulphur dioxide concentration in the stack gases, and abandoned before final testing and adjustments could be made, it is reasonable to expect that the percentage of solids removed by the processes could and

3. See selected bibliography at end of this paper.

4. See selected bibliography at end of this paper. 
would have been increased considerably. Recent experience with similar problems certainly warrants such a statement.

They also installed a treater in a sulphuric acid plant a few miles north of Berkeley, California, which successfully collected all the sulphuric acid mist, but it was not kept in industrial use, because of the existence of certain commercial arrangements which concern sulphuric acid manufacture by the contact process. Mr. Burns superintended some experiments in a sulphuric acid plant at Bayonne, N. J., a few years ago, the object being to remove dust from hot burner gases. Experience with details of the processes were more limited then than now and the result was that the testing was discontinued before conclusive results were obtained. It may be of interest that recently we undertook this same problem at another plant and the results were successful and a commercial installation is now to be made. The difference between the results at the respective places was due more to mechanical features and control than to any inherent faults of the electrical precipitation processes, even as originally applied.

- Dr. Cottrell and his associates also successfully employed high potential electricity for separating water from crude oil, when these ingredients were obtained from the California oil wells in an emulsified form, but as these patent rights are not a part of the Research Corporation's holdings, no further mention will be made of them in this paper.

Mr. Walter A. Schmidt ${ }^{5}$ undertook to adopt the electrical precipitation processes to the existing conditions at the Portland Cement plant near Riverside California and early in 1912 had made excellent progress, having up to that time installed one complete treater unit for the gases from one rotary cement kiln. Ten units are now in continuous operation at that plant, collecting in the neighborhood of 100 tons of dust daily.

After experimental work had progressed satisfactorily at Riverside, and the Balaklala installation had ceased operating because of the sulphur dioxide controversy, Messrs. Howard and Rathbun started experiments with the electrical processes at the Garfield Smelter of the American Smelting \& Refining Company, the immediate problem being to remove the solids from the gases coming from copper matte converters. These gases carry a considerable quantity of lead compounds together with other metal values. The principal object of the fume col-

5. See selected bibliography at end of this paper. 
lection was to save the values. Mr. Barker succeeded Mr. Rathbun in this work, the latter having resigned to accept a position as Chief Electrician of a large smelter in British Columbia. When the Research Corporation was organized, the work at Garfield was still in the experimental stage. During the summer and fall of 1914, the large installation at Garfield was completed and the entire volume of converter gases is now being successfully treated, with a reported collection of over 95 per cent of the suspended matter. The Garfield installation is in the territory controlled by the Research Corporation.

The above condensed record shows the extent to which the electrical precipitation processes had been developed when work was started in the eastern part of the United States by the Research Corporation. Naturally, it may be surmised that almost innumerable schemes were tried and that many elaborate and complex laboratory experiments were conducied prior to 1912 in connection with efforts to explain the apparent inconsistencies and to make the processes most widely applicable. It seems that in the earlier periods of scientific and complex technical work, ic is the usual experience that a great amount of . time and effort is devoted to very intricate and difficult methods, and that the simpler and more practical methods of accomplishing certain desired results are not adopted until a later period.

It is reasonable to expect that processes for this kind of work must operate simply and reliably if they are to succeed in the greatest variety of problems and to the highest degree. The induction motors of modern types represent a good model to be kept in mind when developing such a field, as they perhaps come nearest to being foolproof of any electrical apparatus now in general use. This goal may be too much to hope for electrical precipitation but it is well to strive for it. Our plans and efforts have been guided considerably by such model as we have striven to improve and standardize thcse processes.

It does seem strange at first thought that the electrical processes were first successfully used in a commercial way for the precipitation of sulphuric acid mist, which material had previously been, and even to this date is, one of the most difficult materials to collect by ordinary methods; but, happily, by the electrical processes, this material is handled with greater ease than most any other. This mist consists of extremely small drops of sulphuric acid, generally containing some free water.

The following brief statement is made at this point for the bene- 
fit of those who may not be so informed. To remove from gases either solid or liquid particles carried in suspension therein, the present method is to subject the gases and suspended particles to the action of a strong electric field maintained between so-called " collecting electrodes " and "discharge electrodes," the latter being insulated from the former and connected to a suitable source of high electric potential. Alternating current fails to give the kind of field most desired, therefore the polarity of the "discharge electrodes" generally is kept fixed, the current flowing between the electrodes through the gases being essentially unidirectional. This is accomplished in practise by siepping up single phase alternating current to a rated potential of say 100,000 volts, connecting the "discharge electrodes" to the high-potential terminals of the transformer in such a manner and for such time as to produce the most suitable discharge from the "discharge electrodes" and maintain the desired potential difference between the opposed electrodes. The high-potential alternating current is changed into high-potential direct current by means of suitable rectifiers. The gases are rapidly ionized and the suspended particles removed by the forces acting between the electrodes. Maintaining the "discharge electrodes" negative with respect to the "collecting electrodes" is the general rule. By use of apparatus designed by us, 250,000 volts a-c. has been successfully rectified and efforts are now under way to raise this figure to a much higher value. However, the diffculties encountered in handling such pressures are so many that these extreme potentials may not quickly come into general commercial use, in the immediate future at least.

The potential difference between electrodes up to 1912 seldom exceeded $50,000 \mathrm{r} . \mathrm{m}$. s. volts. In some instances the potential gradient near the so-called "discharge electrodes" was very low and a brush discharge or corona was not readily obtained unless a pubescent surface was employed. This improvement in electrode surface is used at present in certain cases, but in most of the problems it is not considered particularly necessary. As the work developed, higher potentials were used and thus other fields were opened to the processes.

The electrical equipment must be of such design and construction as to be suitable for the peculiar type of circuit, and it should be compact, economical and foolproof and still allow and insure uninterrupted operation where desired. The transformers must be strongly built, but not too expensive. The 
treater proper, which contains the so-called " discharge electrodes " and " collecting electrodes," past which the gases travel, must be of such material and construction that corrosive gases, if present, cannot too quickly destroy it. It is good practise to design the treaters of ample proportions, easily accessible to the electrodes and insulators, and with due regard to conducting the gases into and out of it and to the location of flues, furnaces, stacks, buildings, etc. Under some circumstances it is desirable to treat the gases while traveling horizontally, while in others a vertical gas flow should be adopted. Sometimes special types of electrodes must be employed, but the variety of problems and conditions is so great that it is not considered desirable to endeavor to prescribe any general rules in this regard.

The treaters must be arranged so that the dust, fume or liquid may be readily removed after deposition. In some problems a leakage of air into the gas to be treated is not harmful, while in others, such as the burner gases in sulphuric acid manufacture, dilution is objectionable.

Suppose that the treater proper has been correctly designed, constructed and installed, and that the electrical equipment is suitable and in proper adjustment. It may be found that many and more difficult problems are yet to be solved; because a plant owner will not be satisfied unless the entire installation, of which the electrical apparatus and treater are but parts, operates properly; particularly, the furnaces or other source of fume or dust must continue to produce quality and quantity as before. Detrimental influences should not be introduced into any portion of the plant. Actual examples have been encountered which illustrate the points quite well. In one case the flues were designed and instailed by the plant's own engineers in such a manner that the natural draft was somewhat interfered with. In order to justify their own work they declared that the electrical processes had made it impossible to operate the furnace as before; but the fact is that the processes had nothing to do with the results, as it was entirely a problem concerned with utilization of natural draft. In another case the processes were blamed on the ground that the collected product could not be conveyed by screw conveyors, although the plant's engineers admitted that they never had been able to convey similar material by that method. In the former case, we obtained our own gas data at the plant and then redesigned and changed the flues and stack, keeping the treater and processes as they were, and then were 
able to demonstrate to and convince their engineers that not only could their furnace be operated and the dust removed from the gases by the electrical processes simultaneously, but, moreover, the capacity of that particular furnace was increased so that it produced about 10 per cent more finished material than any other similar furnace they had, and also the quality of the product was even better than before. In the other case, the material was slightly modified in chemical composition by introducing more dust into the gases, and the result has been that the material is now being conveyed and the electrical processes are therefore considered successful, although the change was merely one of local conditions having no direct bearing upon the processes themselves.

As has been stated above, the difference between success and failure is sometimes very small, and yet some persons remain somewhat skeptical even after a "near-failure" has been converted into a success, because they are unable to see just how the seemingly unimportant (to them) changes could produce such a "magic" effect. One could relate some really amusing incidents in this connection. In one particular case, when it seemed to be impossible to satisfactorily collect the dust from certain gases by means of the processes, a number of things were tried in regular order, hoping that some of the schemes would bring a solution of the problem. It is interesting that the very changes that eventually insured success had previously been discarded as worthless in earlier work, owing to false assumptions as to some of the apparently minor details. Such experiences indicate the wisdom of weighing most carefully the effect of all local conditions when difficulties are encountered. For some time past, however, more rapid and sure progress is made, because it is much easier to detect the causes of the various troubles, and once known they are quite readily corrected.

A partial record of the results obtained since 1912 is given below.

The first problem undertaken since that time was to recover the valuable fumes from silver refinery gases at the Raritan Copper Works, Perth Amboy, N. J., after they had passed through a water scrubber which was supposed to recover practically all of the values. In this installation very corrosive gases were encountered. Many materials of construction were experimented with,- - even ductile tungsten, which, at that time (1912), was not readily obtainable. The construction problem 
finally was solved by the use of heavy cast iron in parts and a mixture of lead and antimony for other parts. Insulation and natural draft troubles also were encountered but finally they were overcome with the result that the installation has already saved several thousand dollars worth of valuable fume. The power consumption is about 2.5 to $3 \mathrm{kw}$. and the voltage averages about 35,000. Recently we have installed some 12-inch and some 24-inch diameter lead pipes for additional treaters which are of very simple construction. These operate very successfully and mark a distinct advance over the old type treater in several respects. Lately there has been installed at this plant a 10-kv-a., 25-cycle single-phase 100,000-volt transformer, a 500-rev. per min. motor-generator set, and a large rectifier. With this equipment greater spacing between electrodes is possible and the operation is generally improved. Occasionally some of the deposited fume, which is a good conductor of electricity, drops between electrodes and draws a heavy arc. This used to cause the automatic circuit breaker to open and an auxiliary circuit to ring a bell and notify the attendant. An automatically operated mechanism was developed and installed thus overcoming this troublc and increasing the values recovered.

A small treater was installed or the Vulcan Detinning Company for removing hydrated tin chloride from a small quantity of gases, these being the exit from a chlorine detinning plant. The hydrochloric acid, free chlorine and tin chloride together consticuted one of the worst fumes for human beings that we have yet encountered. The tin chloride and a portion of the acid and the chlorine were recovered but the final installation never was completed because the plant manager feared that water vapor might be drawn back through the treater and into the anhydrous gas lines, thus closing them and stopping operations due to a solid compound resulting from the reaction between the water and the anhydrous tin chloride. The original treater insulation was not fully satisfactory, although it permitted most successful operation if it was occasionally cleaned. A modified treater of simple construction was suggested whereby all the remaining difficulties could have been overcome, but it was not installed. The electrical equipment easily and completely precipitated the tin compounds for which it was installed, but for various commercial reasons the use of the processes was discontinued. With the present knowledge and the experience gained since then, the problem could be easily and cheaply solved 
even with the original electrical equipment. The problem of insulation at the point where the high-tension current entered the treater was really the most difficult to solve because of such fumes; the later designs overcame this.

During the time a treater was first operated by the Balbach Smelting \& Refining Company, on the gases from cupel furnaces, the value of the material recovered did not warrant its continuous operation. It was believed that the losses were considerably greater than the actual collections indicated, so the treater was shut down and experiments thereafter were conducted upon a small scale, because of the greater ease of changing conditions with a small apparatus than with the large treater. One purpose was to obtain a close estimate of the total fume values being lost from the furnaces, as this would decide whether work would be continued. Results of operations to date are highly encouraging and success upon the final scale is assured. The volume of gas is about 10,000 cubic feet per minute.

Opinion was widely divided as to the probability of successfully adapting the processes to Waterside Station No. 2 of the New York Edison Company, the problem being to remove cinders from the boiler plant gases. Nevertheless, for various reasons, efforts were made and the following conclusions reached: There was not sufficient available space for treaters in the building to insure successfully treating all the gases, especially without imposing prohibitive restrictions upon the natural draft. Tests under ordinary conditions of installation showed that the cinders could be removed while moving at a velocity between 10 and 15 feet per second without using water and that they could be cleaned at a considerably higher gas velocity when water was used; but the consensus of opinion was that tests should be discontinued until better assurance of success in this problem might be obtained. Perhaps this same type of problem will be again undertaken at some future date, as the prospects of success are much brighter now than formerly.

Our tests at the plant of the Orford Copper Company, on a semi-commercial scale were successful. Various kinds of gases were treated and a large amount of data obtained which would be useful when the full scale apparatus was installed. The various flues, stacks, etc. were studied, plans and specifications for equipment to handle all the gases were prepared and submitted with our report. The values recoverable from the gases apparently would not be sufficient to warrant the heavy installa- 
tion expense; therefore, before deciding to incur the financial risks incident to such a large installation, especially when only an alleged nuisance was involved, it was decided to await further developments. It is quite likely that the large installation eventually will be made at this plant.

At the plant of the Hooker-Electrochemical Company, a large volume of air, containing a small percentage of chlorine gas, is treated for the removal of the latter. Hydrated lime dust is used to assist in the removal, and a few tons per day of weak bleaching powder are collected. The volume of gas is about $30,000 \mathrm{cu}$. ft. per min., with a power consumption of from 3 to $5 \mathrm{kw}$. Weak bleaching powder, chlorine gas and hydrochloric acid are not conducive to a simple insulation problem, as can be readily imagined; nevertheless it was successfully handled, even for 50,000 volts. In this case our most difficult problems have not been concerned with the electrical processes specifically, but, on the contrary, have been to obtain a steady introduction of hydrated lime into the gas and at a given rate. Other mechanical problems were met and solved. Occasionally it has seemed odd that those concerned only with these electrical processes should have to devote any time and effort to extraneous matters, but unless they do, the electrical processes are liable to suffer condemnation; hence the assistant engineer in charge must not only solve his own problems but must also solve the other man's problems (although they may be only remotely connected) in order to have his own work accepted.

The gases from a hand-fired 80 h.p. boiler at the U. S. Bureau of Mines are treated for the elimination of black smoke when certain coals are being tested and it is not expedient to prevent the production of smoke. The removal of the carbon and other particles of the smoke is accomplished quite readily but the question of suitable disposal of the collected soot is still under consideration and some further tests are being made. As is to be expected, the results obtained thus far indicate that it is best to prevent formation of smoke whenever feasible, and not adopt methods for collecting it. But it should be noted that there are many places where, for local reasons or for immediate economy, it is best to install the electrical processes, as by them complete elimination of the smoke can be obtained readily. The treater contains twelve iron pipes 12 in. in diameter by 12 ft. long, through which the gases pass. The high-tension electrodes are placed vertically so as to subject the gases to the forces 
in the electric field throughout the entire length of the pipes. A pressure of about 50,000 volts is used, and the power consumption is approximately one $\mathrm{kw}$. The exciting current of the transformer is considerably higher than that of later transformers, and the power factor is low in comparison with other and more recent installations.

Fig. 3 is reproduced from a photograph which shows the general arrangement of the treater.

Figs. 4, 5, and 6 show the effect of the electric field upon the smoke, the first showing the effect when the electric circuit is open, and Fig. 5 shows conditions 30 seconds later. Fig. 6 plainly illustrates how the smoke began to show itself at the stack top when the current was stopped. Figs. 7 and 8 show the voltage off and voltage on. The results of the work to date may be summarized as follows: The smoke can be precipitated readily; the insulation problem is not now a difficult one. The treater can be constructed and operated within the limits of good practise with regard to corrosion; the power consumption is low; there need be no difficulty in operating with natural draft if there is sufficient room to build breachings, treaters and stacks. The apparatus can operate continuously, requiring but little attention; the most annoying question is what disposition shall be made of the collected material? It is expected that in the next few months something more definite can be stated regarding this latter feature. Mr. A. F. Meston has charge of the details of this installation.

Gases from sintering machines and roasters at Salida, Colorado were to be treated, but the tests made in the latter part of 1912, did not indicate that the values in the gases at the time was sufficient to warrant the expense of installation. The plant management had been endeavoring to reduce their lead losses to a minimum by close chemical control of the material fed to the furnaces. It is possible, however, that this plant may find that it is more desirable to use the electrical processes than to exercise such careful control over the charge. Recent developments have so reduced installation costs that the problem may be reconsidered, especially since the processes are now in successful use on similar gases at another lead smelter.

Tests were conducted on a semi-commercial scale at the Kings County Foundry with results showing that complete recovery of the fume was feasible. The gases come from cupola furnaces in which old tin cans and other metal scrap are reduced to a 
poor grade of iron which is made into sash weights. The fumes consist mostly of tin, lead and zinc oxides and the quantity per day is considerable. The cost of separating and refining the metals, when they are in the proportion as shown by analyses of the collected material, is such that the expense of the installation has not yet been incurred by the company which proposed to operate it, and therefore the scheme has remained dormant since the completion of our tests and submission of our report. When a process has been perfected for treating these fumes economically so that the tin, lead and zinc can bring something close to their market value, the field is a good one in which to build up another by-product industry. As these sash weight foundries are operated at present it would be necessary to install a fairly extensive system for cooling the gases down to a reasonable working temperature. Of course, such apparatus increases the cost and helps to make difficult the profitable collection of these fumes at the present time.

Elaborate tests upon gas volumes, composition, temperature, fume content, etc. were conducted for the Chase Rolling Mill Company in order to secure reliable data upon which to base designs for full scale commercial installations. The fume is mostly zinc oxide originating at the crucibles in which zinc and copper alloys are produced. Many tests were conducted with the electrical processes while the gas conditions were varied as to velocity, temperature, etc. The results were very gratifying, showing that the financial returns would pay well. Plans have been prepared for large commercial installations at the various locations and a contract for a portion of the installation has been awarded. Some very valuable data and information were obtained in the investigations at this plant and these will be useful in many other installations also. Early in the testing work at this plant such discouraging results were obtained that some of our own technical men considered it to be a hopeless task, and it was with great difficulty that they were induced to renew the work and carry it to so favorable a stage as it is now. The management of the plant kept its faith throughout the trying periods when tangible results seemed to be the exception, and its course is to be commended. Mr. P. E. Landolt had charge of the details of the work at this plant.

Prof. A. H. White has succeeded in cleaning the entire make of illuminating gas at the plant of the Ann Arbor Gas Company by means of the process, the installation requiring a very small 
PLATE XXIII.

A. I. E. E.

VOL. XXXIV, NO. 4

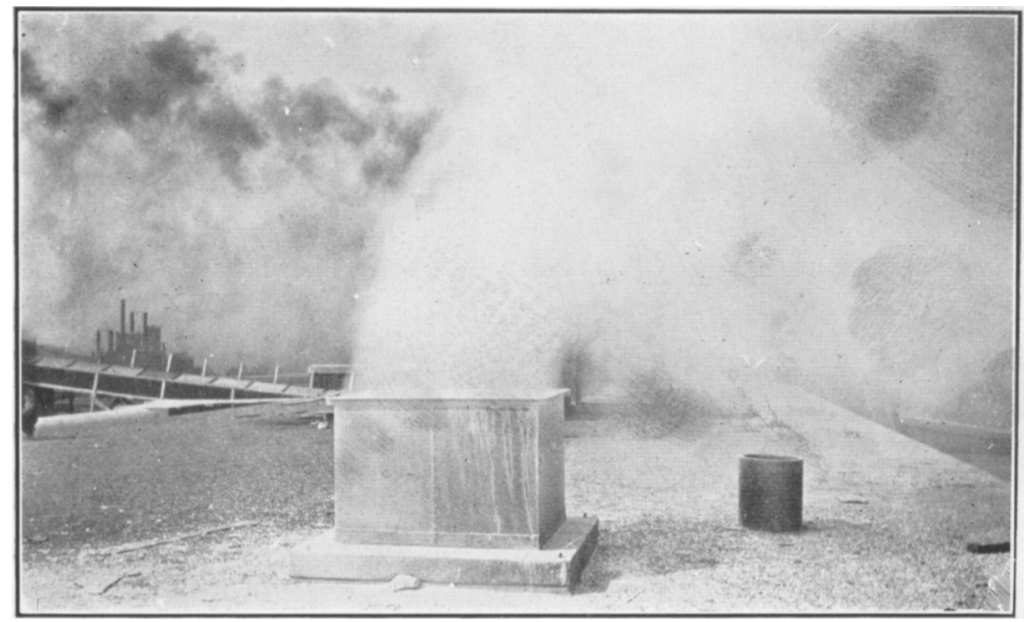

[BRADLEY]

Fig. 1-Exhaust Flue from the Treater at the Hooker Electrochemical Company's Plant at Niagara Falls, N. Y.-Voltage Off.

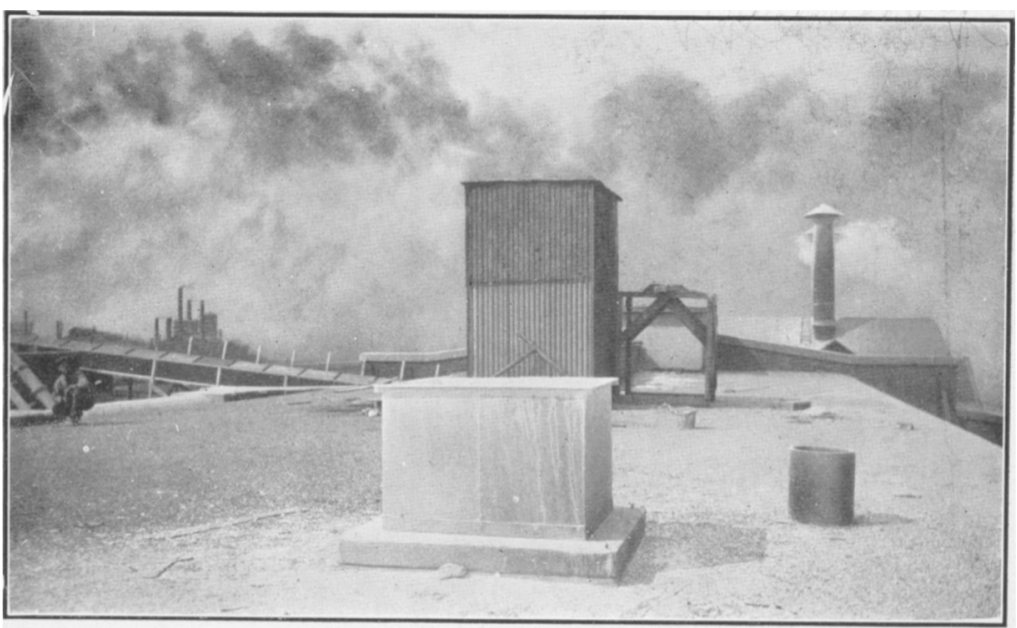

Fig. 2-Exhaust Flue from the Treater at the Hooker Electrochemical Company's Plant at Niagara Falls, N. Y.-Voltage APPLIED 

PLATE XXIV.

A. I. E. E.

VOL. $X X X I V$, NO. 4

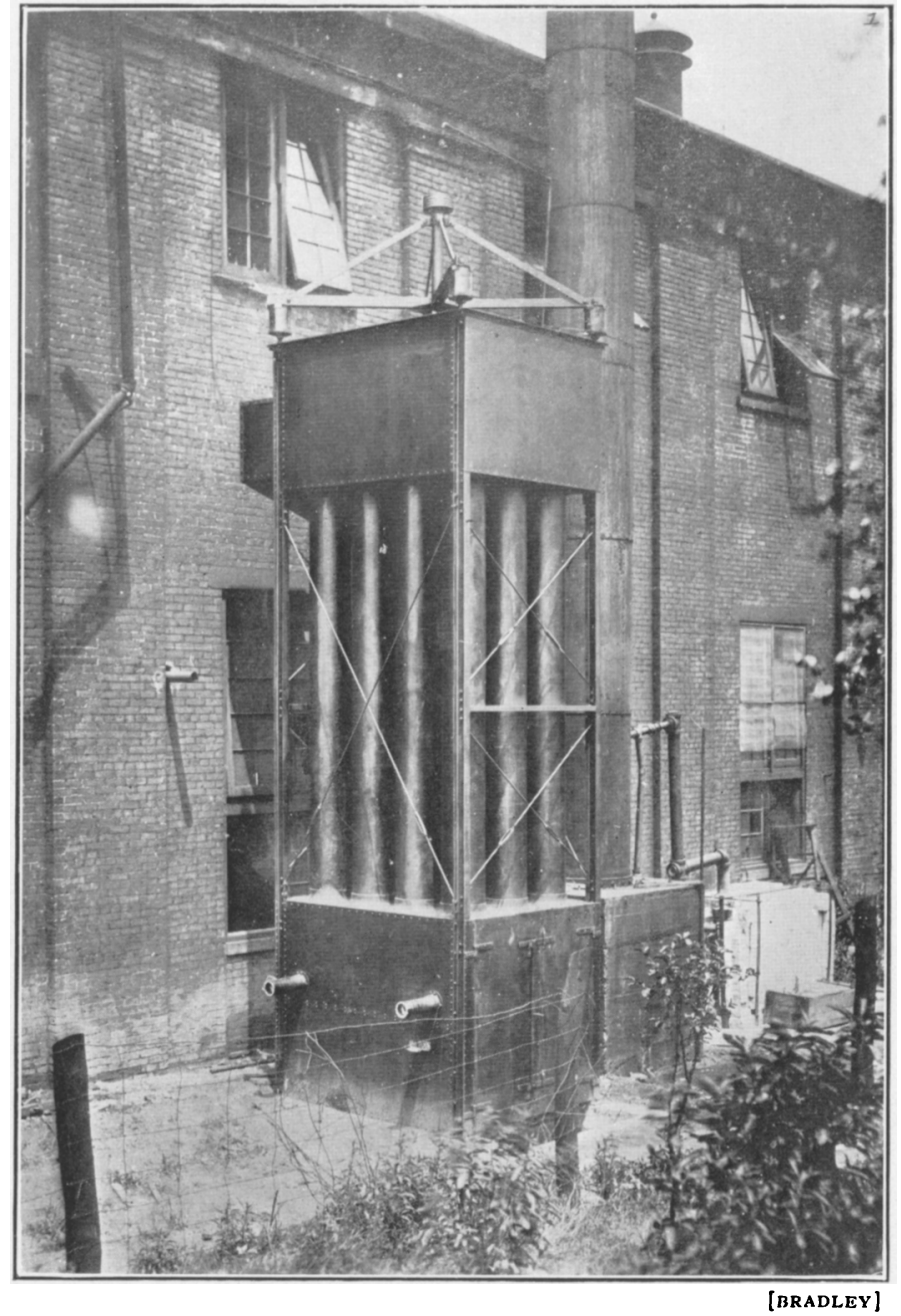

Fig. 3-Buread of Mines Treater-Pittsburgh, Pennsylvania 

PLATE XXV

A. I. E. E.

VOL. $X X X I V$, NO. 4

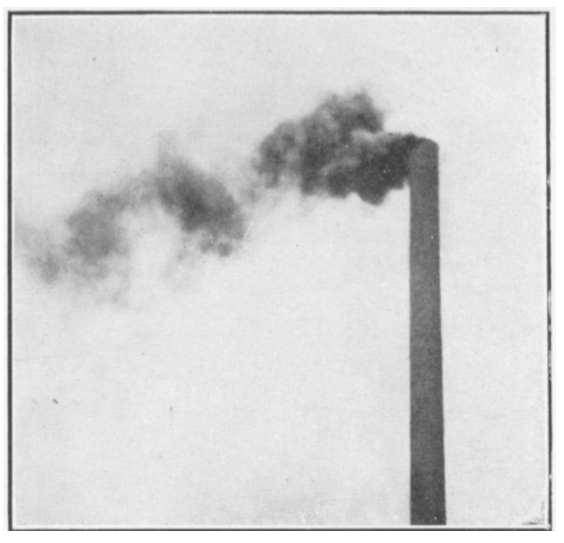

[BRADLEY]

Fig. 4-Top of Stack-Bureau of Mines Treater, Pittsiurgh, Pa.,-Voltage Off

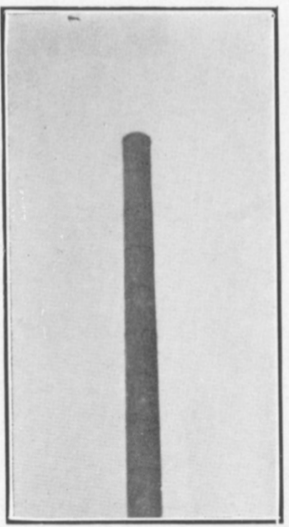

[BRADLEY]

Fig. 5-ToP OF STACKBureau of Mines Treater, Pittsburgh, Pa., THIRTY SECONDS AFTER APPlication OF Voltage to TREATER

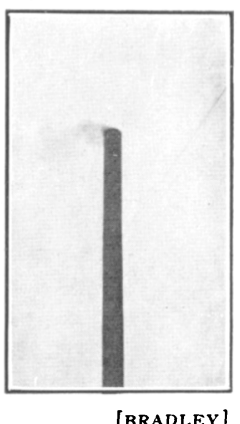

Fig. 6 - TOP OF STACK-BUREAU OF M I NES TREATER, Pittsburgh, Pa.,SEVERAL SEC ONDS AFTER VOLTAGE IS Cut OfF

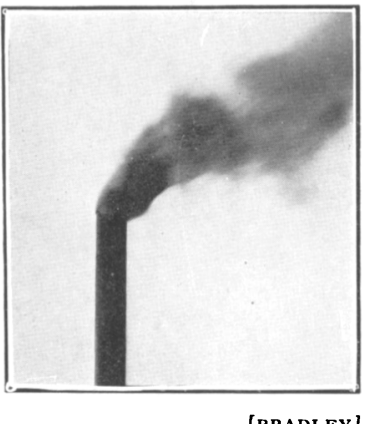

[BRADLEY]

Fig. 7-Top of STACKBureau of Mines Treater, Pittshurgh, Pa.,-Voltage OFF

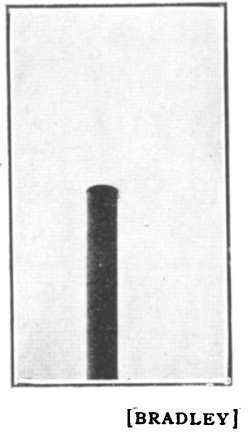

Fig. 8 - TOP OF STACK-BUREAU OF Mines TREATER Pittsburgh, Pa.VOLTAGE ON

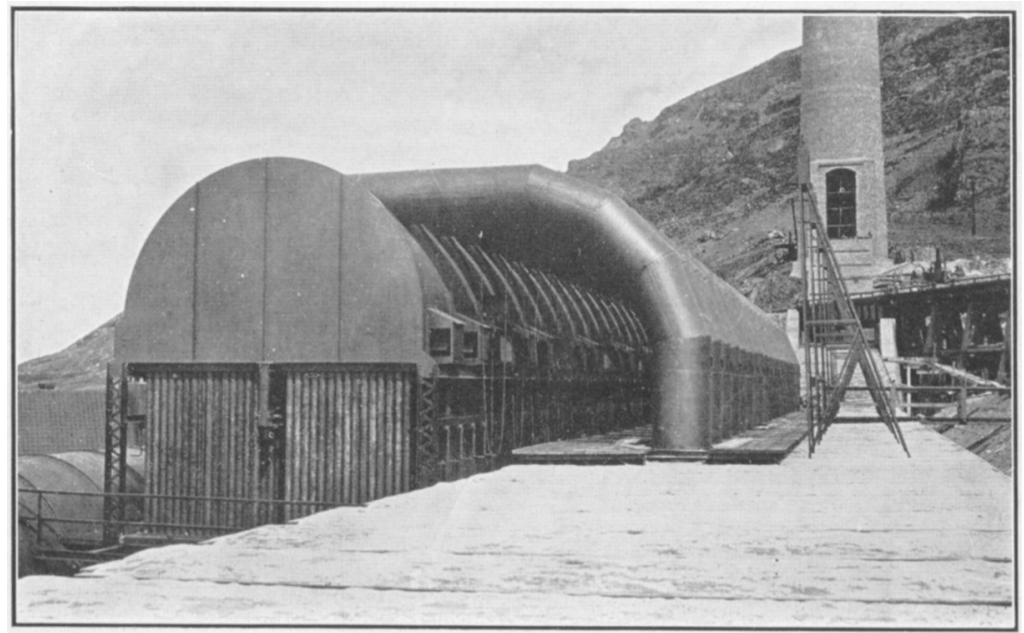

Fig. 9-General View of Treater at Garfield, Utah [bradley] 

amount of power. The tar removal was practically complete. At times during the testing period the gas velocity past the electrodes was over 30 feet per second. The installation is very simple and compact, and judging from his reports, should warrant its rapid and general adoption as standard equipment for this purpose by gas manufacturers. Prof. White plans to push this development quite vigorously throughout the summer vacation. His work is described in the American Gas Light Journal.

An installation at Omaha, Nebraska for collecting sulphuric acid mist arising from so-called "parting kettles" in a silver refinery, practically identical with the Selby, California, installation was also very successful. Mr. H. A. Burns had charge of the details of this installation.

The installation at Garfield, Utah is fully described by $\mathrm{Mr}$. W. H. Howard in the Bulletin of American Institute of Mining Engineers, August, 1914. It consists of seven units each of 360 five-in. pipes, 2520 in all. The volume of converter gases treated is approximately $200,000 \mathrm{cu}$. $\mathrm{ft}$. per minute. The collected material is quite high in lead, and several carloads have already been shipped for refining. It is a large, well constructed installation and is reported operating very successfully, the collection being about 95 per cent of total solids. Semi-commercial tests also were conducted upon main flue gases, coming from blast furnaces, roasters and reverberatory furnaces. These tests likewise were successful and eventually these gases also may be treated by the processes.

The electrode spacing is $2 \frac{1}{2}$ in., the potential about 30,000 volts, and the power consumption approximately $50 \mathrm{kw}$. The building which contains the motor-generator sets, rectifiers, control apparatus and switchboard panels is one to be proud of. $\mathrm{Mr}$. Howard was assisted by Mr. R. F. Barker to whom the details. were delegated.

Fig. 9 gives a general view of the treater. It is divided into seven electrical and mechanical sections. The converter gases, mixed with more or less air, come from the converter building through a long steel balloon flue, drop considerable of the heavier particles throughout the length of the flue, then enter the bottom header, pass upward through the five in. pipes, into the upper header, then through the long radius pipes into the main flue which also carries gases from other parts of the smeltery. The illustration was made prior to actual connection of the flue to the new stack which is in the right background. 
The semi-commercial treater used early in the testing work at Garfield was subsequently shipped to Murray, Utah, and tests were conducted at the lead smelter with excellent results. The smelter already was equipped with a large and expensive baghouse, and for this reason it was not necessary to immediately install the electrical processes. The analytical results showed nearly 100 per cent of the suspended particles of fume and acid removed in the electrical tests, thus proving the effectiveness of the processes.

Small scale tests were conducted on gases from sintering machines at Tooele, Utah, carrying large amounts of lead, elementary sulphur, etc., and upon gases from roasters, converters and blast furnaces. In all cases the results were satisfactory. Two large units are now in successful commercial operation on the sintering machine gases and it is planned to install several others on these gases as soon as possible, and later to install treaters on other flues at this plant as well. Each of the two units contains 48 pipes 12 in. in diameter by $15 \mathrm{ft}$. long, placed vertically. The electrode spacing is six in., the volume of gas treated is approximately $20,000 \mathrm{cu}$. ft. per min., the power consumption measured at the transformer at present is less than five kw., the recovery of fume, when the treaters are not overloaded by forcing the blowers at the sintering machines, is practically complete. The fume contains a fair percentage of elementary sulphur, which formerly wrought havoc with baghouse installations, especially when it exploded. The potential on the treater as indicated by transformer ratio and primary voltage, is around 70,000 volts. At this plant also some changes in the metallurgical operations have resulted in a considerable reduction of the values lost in the fumes, hence the electric processes are not called upon to recover as much as was being lost a year or so ago. Figs. 10 and 11 picture the small scale treater operating on these gases, and show the effect produced by the current. Mr. H. A. Burns has directed the detail work connected with the processes at this plant and he has been ably assisted by the smelting company's technical men.

Without having conducted any preliminary tests, a full scale treater was designed, erected and placed in operation for the Goldschmidt Detinning Company. The necessary alterations were very few and unimportant before a complete recovery of the tin compounds was being effected. The temperature of the gases sometimes reaches $800 \mathrm{deg}$. fahr. in the treater itself. 
Occasionally the white fumes and black coal smoke alternate: One can then observe the successive layers of white and black fume precipitated upon the electrodes and by this aid can determine if the gas speed in all compartments of the treater is practically equal. There are nine-12-in. iron pipes, the voltage may range from 60,000 to 80,000 , the power consumption from 600 to 1500 watts. Figs. 12 and 13 show the treater and some of the electrical equipment.

A treater was installed without conducting any preliminary test for the Milk Flour Company, as sufficient experience with the various influencing factors had been obtained to be able to make a successful installation without them. It is a very inexpensive outfit, used for collecting powdered milk, sugar, eggs, malt, grape fruit juice, etc. The powders are obtained from an evaporating plant wherein solutions, emulsions, etc., are deprived of their water by spraying the liquid into a current of hot air. The powder is removed from the gas before it cools sufficiently to allow deposition of the evaporated moisture. Excellent powdered organic materials are recovered in this manner at a small expense. Several very interesting and some fairly important facts were learned from this installation. A small electrical treater was subsequently installed for removing dust from the air before heating it, thus insuring a food product free from dirt specks. It may be of interest to note here that a party once inquired if we could remove bacteria from ordinary air by these processes, and whether the ozone and nitrogen oxides would render the air more healthful. Fig. 14 is a general view of the treater.

In response to a telegraphic request apparatus was shipped to the Washoe Smelter, Anaconda, Montana, to be used for removing valuable metals and acids from gases arising from a modified MacDougal roaster, in which the Anaconda tailings were being subjected to an oxychloridizing roast under the direction of their Mr. Laist. (Bulletin of A. I. M. E., August 1914). The gases at that time were being passed through a scrubbing tower without obtaining a complete recovery of the values. The electric apparatus and treater were quickly erected and tried out but at first with what was apparently unsatisfactory results. As similar phenomena had been encountered elsewhere it was possible to soon show that the cloud emerging from the treater was due to moisture being condensed from the gaseous to the liquid condition upon the gases mixing with cold air, result- 
ing in a condition of supersaturation for the temperature existing after admixture of the gases. It was also noted that if the furnace fires were poked so as to produce black smoke, no black could be discerned in the cloud above the treater when the electric field was on, but this was plainly visible when the current was turned off; - the difference between the white cloud (current on) and the dark gray cloud (current off) being very pronounced. This was a good indication that all solids were being collected and that by a study of certain meteorological tables the proper explanation might be had. The temperature of the gases going to the treater was then so reduced that no cloud would result after the gases had passed through the treater. The results then showed a complete clean-up when the current was on and a dense white cloud above the treater when it was off. Some photographs were taken to show the remarkable effect and also the suddenness with which the electricity produced it. Some very good moving pictures of these fogs or clouds and their elimination were made at the time. Twelve-in. diameter lead pipes, 20 -in. diameter wood stave pipe, and 24-in. diameter stoneware pipes were tested and all proved successful. It was interesting to view the tops of the pipes while in operation. One could see an absolutely clean gas over the cross section, except at a short discance from the pipe on which the cold liquid was deposited. One readily could observe how the fog was produced in a manner similar to a cloud formation when exhaust steam leaves a locomotive stack on a cold and humid day. The name "tea-kettle-effect" has been suggested for lack of a more appropriate and shorter term.

Examples of this effect have frequently been noted during tests elsewhere. The amount of "mist" formed after the gases were discharged from the treater varied with the temperature and humidity of the outside air. A typical calculation of such a condition will illustrate this point:

In a test treater handling $1800 \mathrm{cu}$. $\mathrm{ft}$. of air per min., at a temperature of $152 \mathrm{deg}$. fahr., or $117 \mathrm{lb}$. of gas per minute, the air is saturated at $152 \mathrm{deg}$. fahr. (standard barometer) and carries $0.224 \mathrm{lb}$. of moisture in the vapor form per pound of air, or a total of $26.2 \mathrm{lb}$. of moisture per minute.

Assuming an outside air temperature of $42 \mathrm{deg}$. fahr. and 60 per cent saturation, and a sudden cooling of the discharged air to $52 \mathrm{deg}$. fahr. by mixing with the outside air, the heat transfer is as shown by the following equation: 
PLATE XXVI.

A. I, E. E.

VOL. XXXIV, NO. 4

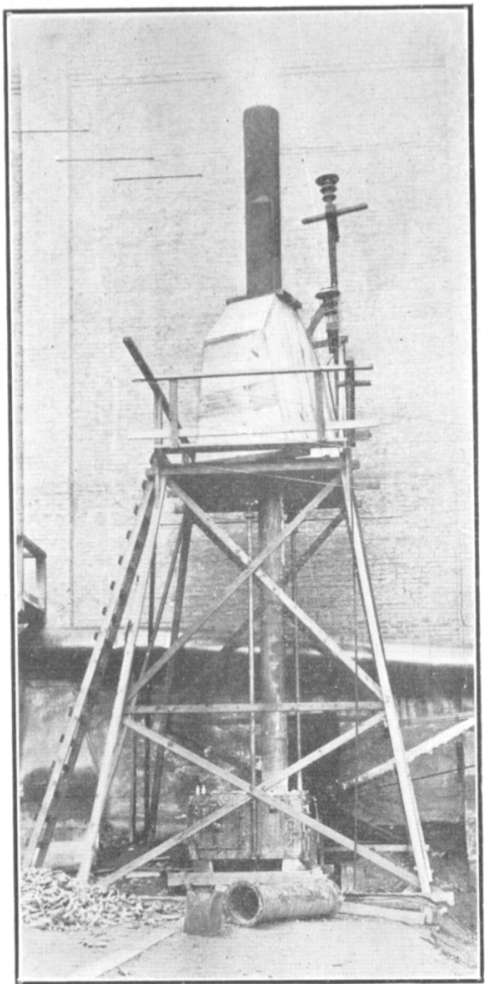

[BRADLEY]

Fig.' 10-Experimental Treater at TOOELE-Voltage OfF

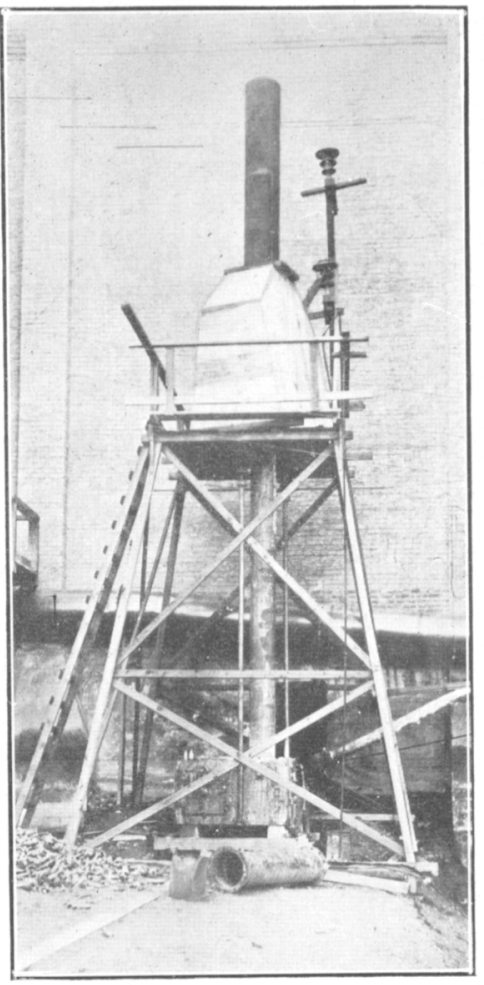

[BRADLEY]

Fig. 11-Experimentai. Treater at TOOELE-VOLTAGE ON

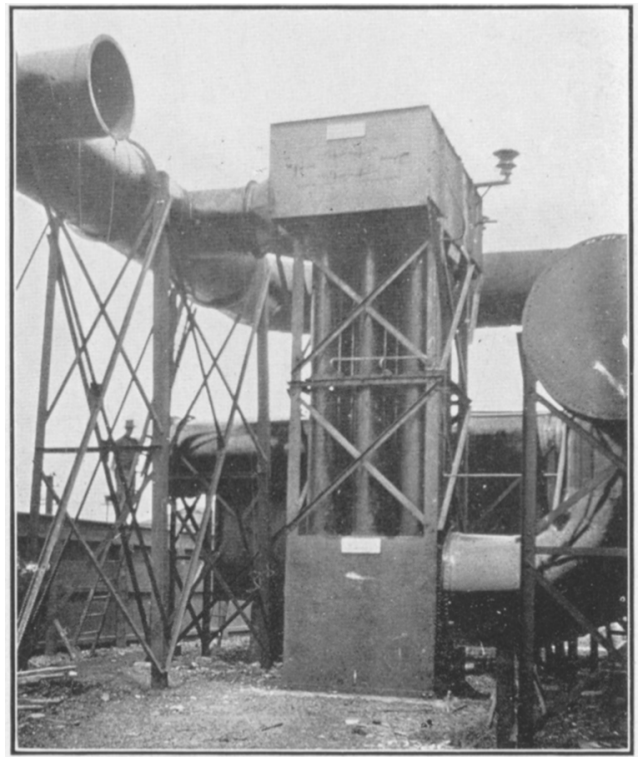

[BRADLEY] 

PLATE XXVII.

A. I. E. E.

VOL. $X X X I V$, NO. 4

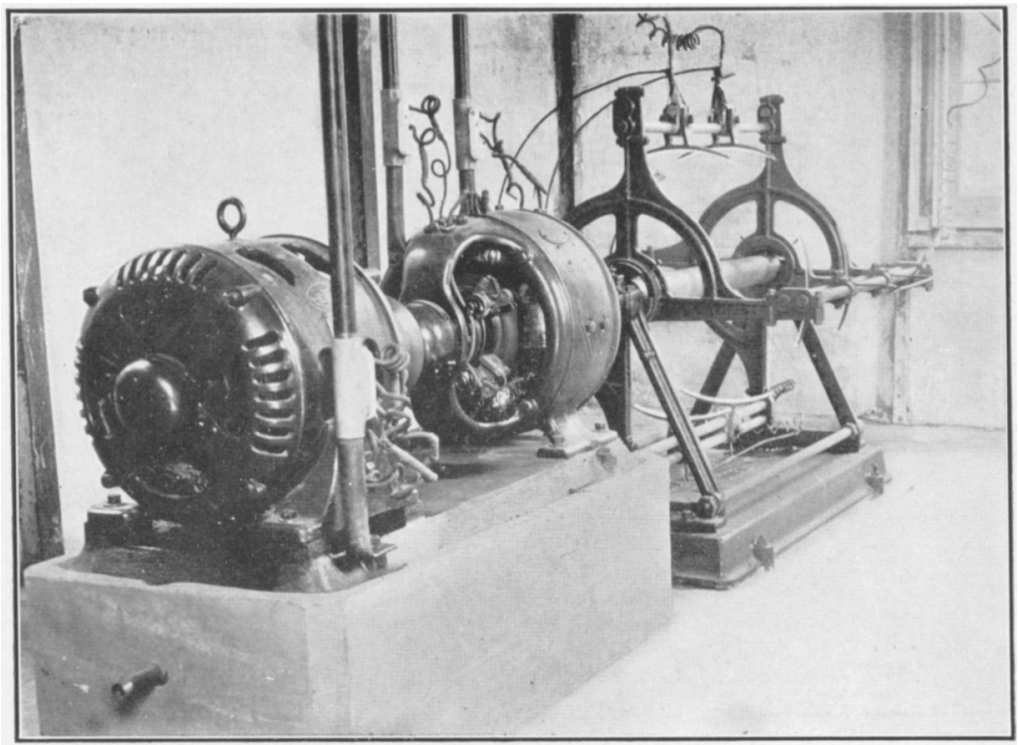

[BRADLEY]

Fig. 13-Portion of the Electrical Eguipment for Goldschmidt Detinning Company

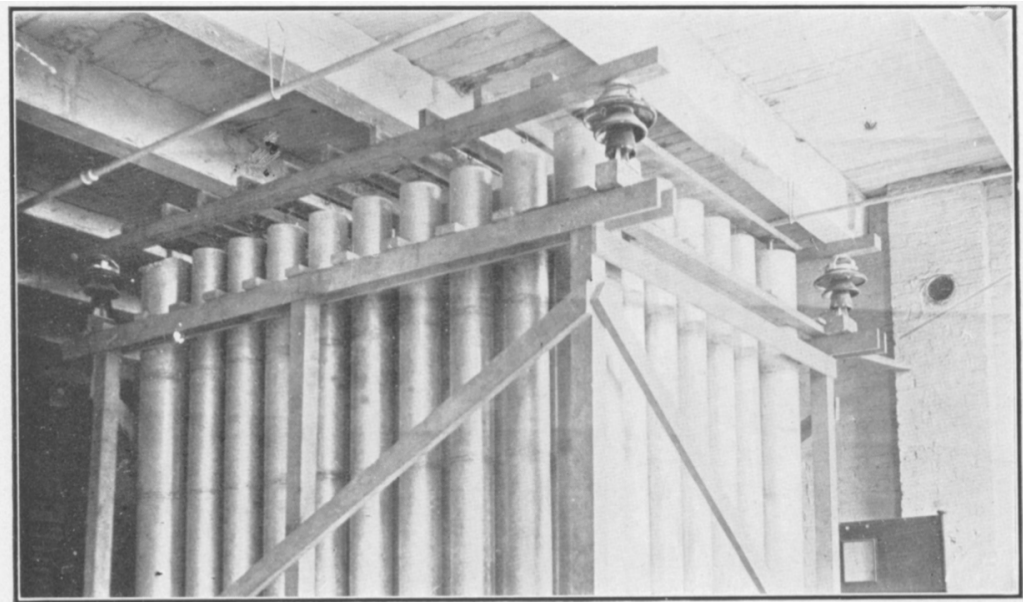

[BRADLEY]

Fig. 14-General View of Treater for Milk Flour Company (LOCATEd in A LOFT Building) 

$(117) \times(0.24) \times\left(152^{\circ}-52^{\circ}\right)+(26.2) \times(0.46) \times\left(152^{\circ}-\right.$ $\left.52^{\circ}\right)=(X) \times(0.24) \times\left(52^{\circ}-42^{\circ}\right)$

Where the specific heat of the air $=0.24$ the specific heat of the water vapor $=0.46$

$X=1 \mathrm{~b}$. outside air per minute necessary to be mixed with the discharged air (neglecting radiation) to effect the cooling to $52 \mathrm{deg}$. fahr. and equals $1670 \mathrm{lb}$.

Then the amount of moisture per $1 \mathrm{~b}$. mixed discharged and outside air is-

$$
\frac{1670 \times 0.0056 \times 0.6+26.2}{1670+117}=0.01791 \mathrm{~b} .
$$

But the saturation point of air at $52 \mathrm{deg}$. fahr. $=0.008 \mathrm{lb}$. moisture per 1b. air, so a " mist" or " fog" will form just above the top of the pipes.

This "fogging out" has been encountered repeatedly in practise. When tests are made during the winter season, a visible "mist" is formed after the gases are discharged from the treater, when warm saturated gases are discharged from treaters. During the periods of dry and warmer weather, the " fogging out" is greatly decreased.

In other cases, where the temperature of the discharged air, saturated with moisture, is only a few degrees above that of the outside air, no mist or fog is produced. It is possible to predict from calculations made in a similar manner whether or not a mist or fog will be produced under any given conditions.

It is further possible to show by calculations whether mixing two or more gases, varying in temperature and in percentage of saturation, in given proportions prior to passing through the treater, will avoid this formation of a mist or fog, when the discharged gases mix with the outside air.

The processes were for some time thereafter used in the tests at Anaconda to check up the furnace losses, as they could be depended on to collect nearly everything that escaped from it, and plans were being prepared for a large installation at the proposed leaching plant, but the later improvements in roasting and leaching made it unnecessary to add salt to the roaster and this in turn reduced the losses to such an extent that it was considered unnecessary to recover the values.

Immediately after the leaching plant tests had been concluded an installation of the processes was made at the Arsenic 
Plant where flue dust is roasted to remove the arsenic from the metal values, and then the concentrated arsenic is recovered and refined. The plan was to separate the mechanically carried impurities from the gases at a high temperature, next cool the gases so as to condense the pure arsenic, and then recover it directly, thus saving a second refining.

This was the first really serious effort made to use electrical precipitation as an adjunct in fractionating components of fume, although -some previous attempts had been made at Perth Amboy, N. J. in our work there on the silver refinery fumes. The results at the Arsenic Plant showed conclusively that it was a feasible method and after sufficient data had been obtained, a commercial installation was designed and started but construction work was suspended on account of the situation resulting from the European war and this installation has therefore not yet been completed; although reports state that it is now going forward.

Messrs. Elton, Dunn, ${ }^{6}$ Kellogg and Mitchell have been handling the work at this plant during the latter period. They have also tested the processes on a semi-commercial scale on the gases from the blast furnaces, converters and roasters, and have obtained satisfactory results. They have even exceeded in size the three ft. pipe originally installed at the Arsenic Plant, by using an iron pipe four $\mathrm{ft}$. in diameter as the collecting electrode, and a 250,000-volt transformer and mechanical rectifier to correspond. This latter is quite inexpensive although it is subjected to such enormous electric stress.

Treating the.enormous volume of gases in the main flue at Anaconda presents several problems. In addition to magnitude there are the numerous problems connected with the handling of the fumes and dust and of their metallurgical treatment, so that it will be some months at least before any very definite progress can be reported. However, the results thus far obtained were so encouraging that the smelting company purchased a license for the use of the processes throughout their plants at Tooele, Great Falls and Anaconda, paid a large cash sum and now they are in position to make rapid progress with their installations. The Research Corporation still has a financial interest in certain elements of the fume which are to bè collected when the processes have been installed. Figs. 15 and 16 show the experimental leaching plant at Anaconda and the electric

6. See selected bibliography. 
PLATE XXVIII.

A. I. E. E.

VOL. XXXIV. NO. 4

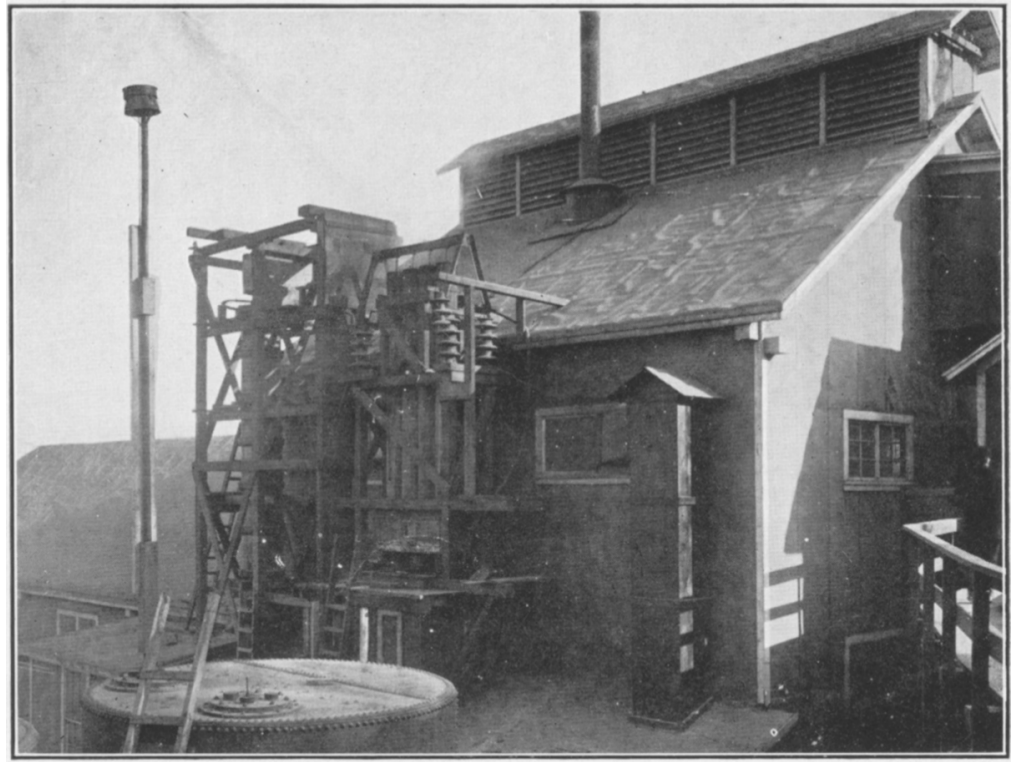

[BRADLEY]

Fig. 15-Eighty-Ton Leaching Plant Electrical Fume Precipitator Current on

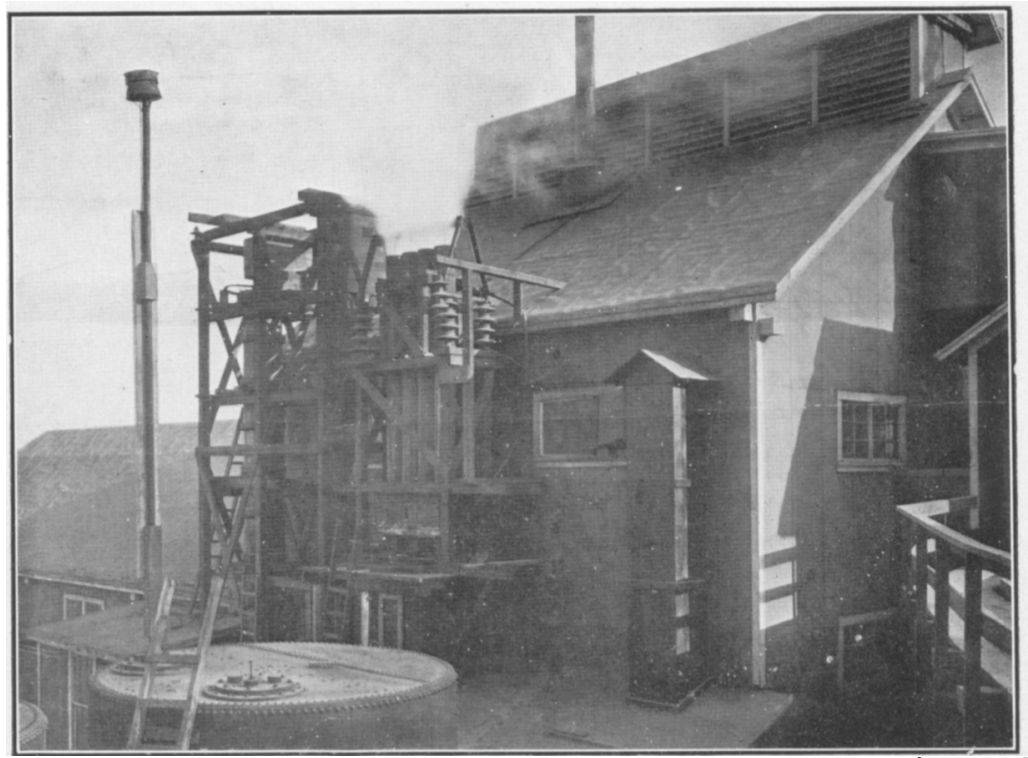

Fig. 16-Eighty-Ton Leaching Plant Electrical Fume Precipitator Current Off 

PLATE XXIX.

A. I. E. E.

VOL. $X X X I V$, NO. 4

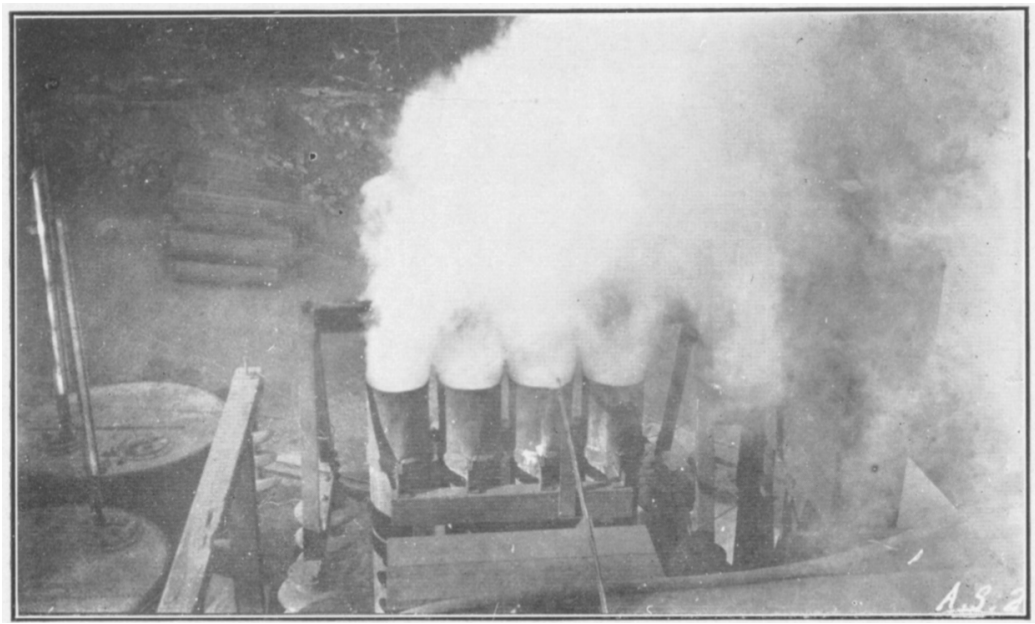

[BRADLEY]

Fig. 17-Anaconda Copper Mining Company-Treater at Experimental Leaching Plant-Voltage Off

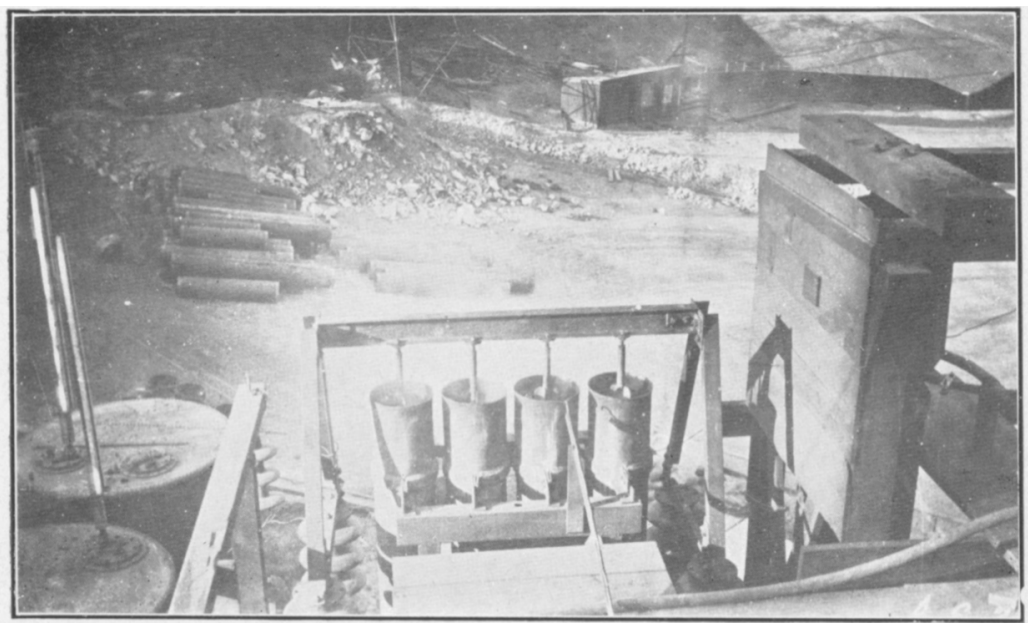

[BRADLEY]

Fig. 18-Anaconda Copper Mining Company-Treater at Experimental Leaching Plant-Voltage On 

PLATE $X X X$

A. I. E. E.

VOL. $X X X I V$, NO. 4

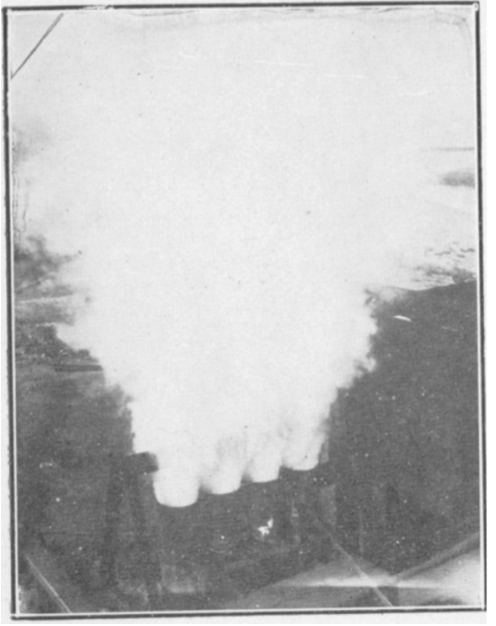

[BRADLEY]

Fig. 19-Anaconda Coppek Mining Company Test Treater -Voltage Off

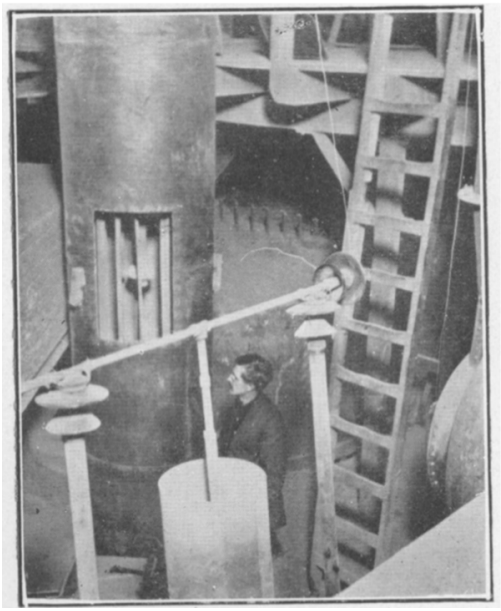

[BRADLEY]

Fig. 21-Experimental Treaters at Arsenic Plant-AnaCONda Copper Mining Company

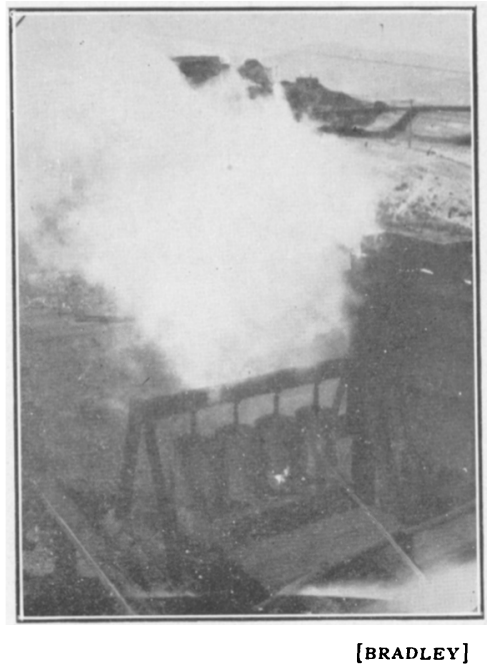

Fig. 20 - Anaconda Copper Mining Company Test Treater -ImMEdiately After the Application of Voltage-Good Example of the Rapid Change between Fumes and Clear Gas

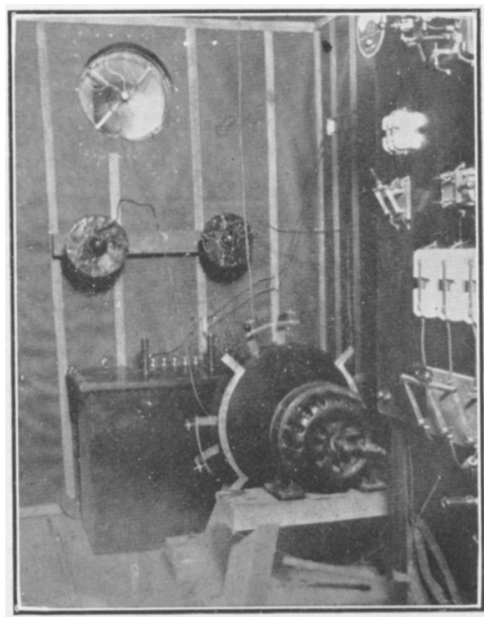

[BRADLEY]

Fig. 22-Electrical EQUipment at Arsenic Plant, AnaCONDA Copper Mining Company 

treaters under various conditions of operation. Figs. 17 and 18 show how completely the fume is precipitated by the electric processes, the views showing respectively the "voltage on" and " voltage off" effects. The fume contained among other things, hydrochloric acid, sulphuric acid, dissolved sulphur dioxide, carbon, compounds of copper, silver, iron and arsenic. Figs. 19 and 20 show the rapidity with which the processes act. In the latter a clear space is visible between the tops of the pipes and the cloud of fume above, the film having been exposed very quickly after the current was thrown on. Although this fume is an excellent conductor, no difficulty was had with the insulation. A potential of 63,000 volts (as calculated from transformer ratio and primary voltage) was maintained on the treater.

Fig. 21 shows various features of the first installation at the Arsenic Plant, the hot gases being treated in the three $\mathrm{ft}$. iron pipe to remove the solids, and the smaller and shorter pipe being used to precipitate a fair sample of the arsenic condensed out of the gases when cooled by admission of room air. The first test gave a precipitate in the second treater carrying 99.4 per cent arsenic trioxide. A portion of the impurity was due to volatile compounds from the wood used for fuel. Coke fuel in place of wood gave arsenic of a higher purity, sometimes reaching 99.9 $\mathrm{As}_{2} \mathrm{O}_{3}$. The electrical equipment is shown in Fig. 22.

At Catasauqua, $\mathrm{Pa}$., is an installation for collecting potash salts volatilized from feldspar. This is operating successfully although the volume of gas being treated is greater than was specified by the owner's engineers. This undoubtedly is the first commercial installation in the United States built primarily for the production of potash salts, the residue being the byproduct. At present the scheme as a whole is still in the experimental stage, but the collection of the salts by the electrical processes is proved. Mr. J. C. Hale has charge of the details of this work. The treater was designed for $12,000 \mathrm{cu}$. ft. per min., but it handles as high as $18,000 \mathrm{cu}$. ft. per min. at times. There are 40 pipes $14 \mathrm{in}$. in diameter by $12 \mathrm{ft}$. long, the electrode spacing being seven in. The temperature of the gases ranges from $500 \mathrm{deg}$. fahr. to $1000 \mathrm{deg}$. fahr. A potential of about 70,000 volts (calculated as mentioned above) is maintained on the treater, low tension alternating voltage about 190 , and amperes 20 to 25 . The power factor varies between 70 and 80 per cent when operating on the hot gases and fume. This same treater has been tested with only ordinary air in it, and at that 
time it was easy to furnish even more than 50 amperes to the transformer without any arcing in the treater. This is a good example of a difference in electrical conditions due to a change in the gas characteristics.

At this point it may be interesting to review some radical differences which we have observed due to certain predetermined changes in the gases, although the treater and electrical apparatus were the same in all tests.

\begin{tabular}{|c|c|c|c|}
\hline $\begin{array}{c}\text { Transformer } \\
\text { voltage } \\
\text { low-tension }\end{array}$ & $\begin{array}{c}\text { Transformer } \\
\text { voltage } \\
\text { high-tension } \\
\text { (by ratio) }\end{array}$ & $\begin{array}{c}\text { Watts } \\
\text { input to } \\
\text { transformer }\end{array}$ & $\begin{array}{c}\text { Milamperes } \\
\text { line to } \\
\text { treater (d-c.) }\end{array}$ \\
\hline 190 & $\begin{array}{c}\text { 26,000 } \\
190\end{array}$ & 100 & 1.0 \\
190 & 26,000 & 740 & 4.0 \\
\hline 235 & 32,000 & 930 & 19.0 \\
\hline 235 & 32,000 & 1600 & 35.0 \\
\hline
\end{tabular}

In neither of the above tests was the potential raised to point of spark-over, but the following figures taken from another set of tests, show plainly the difference in the amount of current which can be passed in a given treater and the apparent potential reached just before spark over occurred. The only factor changed was that in the latter case the gas was slightly modified or conditioned.

Readings taken at voltage just under the sparking potential:

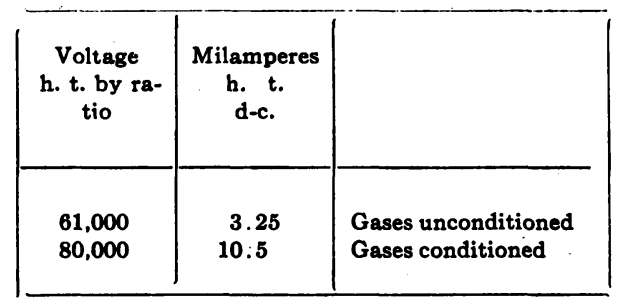

It will thus be seen that it is difficult, if not impossible, to predict what the power consumption and voltage may be for a specified gas until actual tests have been made. The considerable rariety of gas conditions already encountered has made 
it possible to divide gases into classes. Furthermore, methods have been developed whereby a close approximation of the required power and voltage may be obtained from the results of small scale tests.

With a large treater containing many electrodes the effect of the corona load upon the transformer and source of e.m.f. is different from an ordinary resistance load, due to the fact that above a certain point the current flowing through the gas between the electrodes increases more rapidly with a given rise in potential than would be the case if the electrodes were shunted by an ordinary high-resistance metallic conductor. For these and other reasons it is best to employ certain potentials and electrode arrangements for some gases and others for gases having other characteristics. Also the mechanical handling of the collected material must be duly considered when designing a treater.

Other problems upon which tests have been made with the processes are mentioned below. The most recent final installation was made in Worcester, Mass. at the North Works of the American Steel \& Wire Company for collecting volatilized hydrochloric acid, thus mitigating or eliminating a nuisance and preventing further damage to surrounding vegetation. The wire company's own tests were so successful that it waived all requirements and asked that an invoice be rendered at once so they could make prompt payment and close up the account. No experimenting was required on this installation thus testifying to the thoroughness with which the preliminary survey was made before designing the apparatus. The exit gases are so free from acid that it is almost impossible to detect a trace of it even by delicate chemical methods. Table I gives the results of some tests on this installation conducted by the engineers of the American Steel \& Wire Co. The treater is made of materials which resist corrosion.

In Cleveland, Ohio, at a sulphuric acid plant the gases come from an M. \& H. kiln in which very finely divided zinc sulphides are roasted. The sulphurous gases are to be freed from the suspended particles and then delivered to a Glover tower of a lead-chamber sulphuric acid plant. The gases are to be treated at a temperature of about 800 deg. fahr. to $1000 \mathrm{deg}$. fahr. The gases contain some free sulphuric acid which tends to complicate the insulation problem. However, our semi-commercial tests at this plant showed that the problems could be solved, and pointed the way. 
Designs of several types of treaters were prepared and at a recent conference one design of a horizontal treater was decided upon and it is to be installed at once. There are to be three sections, any two of which will clean the gases. Thus one section may be repaired when necessary. In this problem it is necessary to conserve the sensible heat of the gases and to avoid their dilution with air as this would materially affect the

TABLE I

Cottrell Treater Test-North Works

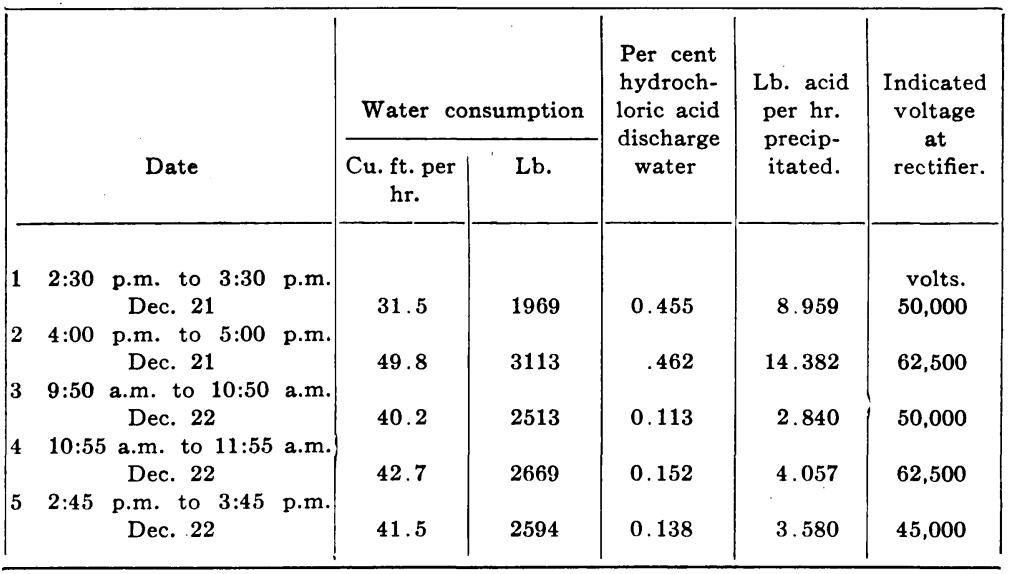

\begin{tabular}{|c|c|c|c|c|c|}
\hline $\begin{array}{c}\text { Temp. of Out- } \\
\text { side air. }\end{array}$ & Humidity & Barometer & $\begin{array}{l}\mathrm{Kw} \text {. input } \\
\text { motor-gen. }\end{array}$ & $\begin{array}{l}\mathrm{Kw} \text {. input } \\
\text { fan motor }\end{array}$ & $\begin{array}{l}\text { Total } \\
\text { kw. input } \\
\text { motor gen. } \\
\text { and fan }\end{array}$ \\
\hline deg. fahr. & & & & & \\
\hline 28 & 66 & $29.2^{\prime \prime} \mathrm{Hg}$. & 2.24 & 0.90 & 3.14 \\
\hline 31 & 66 & $29.2^{\prime \prime} \mathrm{Hg}$ & 2.91 & 0.90 & 3.81 \\
\hline 27 & 69 & $29.4^{\prime \prime} \mathrm{Hg}$. & 2.24 & 0.90 & 3.14 \\
\hline 28 & 69 & $29.4^{\prime \prime} \mathrm{Hg}$. & 2.91 & 0.90 & 3.81 \\
\hline 28 & 69 & $29.3^{\prime \prime} \mathrm{Hg}$. & 1.57 & 0.90 & 2.47 \\
\hline
\end{tabular}

subsequent chemical operations. Mr. P. E. Landolt supervised the details of this work.

An installation for collecting sulphuric acid mist coming from a roasting furnace is under construction for the Standard Essence Company, and since it is so similar to other sulphuric acid mist problems, no difficult features are anticipated.

The problem has been surveyed for the Duquesne Reduction 
Company; gas data as to volumes, temperatures, draft power, etc. was obtained; the volume of gas to be treated is about $11,000 \mathrm{cu}$. ft. per min. at a temperature of $600 \mathrm{deg}$. fahr., tests with electrical equipment showed the probable amount of dust obtainable and indicated how a large treater would operate. Contracts have been let for the full scale installation and work is being pushed as rapidly as possible. The dust and fume contain tin, lead and zinc oxides, from waste-metals. The probable values are so large that an excellent profit is expected. The first treater will contain 48 pipes 12 in. in diameter. Messrs. A. F. Meston and H. D. Egbert handled these investigations.

Similar data to that mentioned above has been obtained at a waste-metals plant of the National Lead Company. The probable recovery of values strongly warrants the immediate installation of the processes and advices to that effect have recently been received. The electrical process tests were highly satisfactory, and enabled one to obtain a dependable opinion as to the values now being lost, practically all of which can be collected readily. Mr. C. I. Weir had charge of this problem. The outcome of the investigations and tests is very gratifying, especially when it. is known that some of their employees declared that their losses were only nominal.

Owing to various reasons beyond our control, tests of the electrical processes for the cleaning of iron blast furnace gases at the Bethlehem Steel Company were delayed. Arrangements now are being pushed so as to commence tests on a fairly large scale at the earliest possible date. It should be feasible to employ the processes either for cleaning these gases for stoves and boilers, conserving the sensible heat contained in the gases when they come from the furnace top, or for gas engine purposes, having cooled the gases previously. Perhaps both schemes will be tested at Bethlehem's plant, although the dry and hot gases will be handled first. The results are expected to have a very important influence in this field.

Arrangements have been made and a license sold to the Baltimore Copper, Smelting \& Rolling Company for installations of the processes to collect sulphuric acid mist, under conditions similar to those at the Selby and Omaha plants, and for collection of valuable fumes from the silver refinery, similar to that of the Raritan Copper Works. Such excellent results had previously been had with these two types of problems and success was so apparent that the company purchased a license for a cash sum, in lieu of royalties. 
At Maurer, N. J. also, the American Smelting \& Refining Company paid a cash sum for rights to use the processes on a limited amount of mixed gases in the arsenic plant, but it is not intended that refined arsenic will be made by using the processes as described for the Anaconda plant. Electrical tests are now in progress and already the indications augui well for success. The mixed gases are apparently more easily treated at high velocities than their sintering machine gases alone. A program of tests is being carried out for the purpose of determining upon the best design and arrangement of the installation.

The plants mentioned above give an excellent idea of the progress which has thus far been made and should convince one that there has been an enormous amount of study and energy devoted to this work considering the age and policy of the organization. Nearly any one of the problems outlined has presented sufficient detail to command serious effort for months. The fact that it was not possible owing to a small treasury, to engage a large force of high-salaried engineers, has made progress perhaps even more difficult than if the organization had been more generously endowed financially. Now that the work has been proved and a fairly large balance is in the treasury, it is the intention to engage more technical assistants, and they will be selected to fill a certain place in the organization. Since it is not possible to have any one who is an expert in all lines of industry, experienced men in the various fields will be selected and charged with the development of that particular field for which he is best qualified. This leads up to the creation of departments for the proper development of the work and already steps have been taken in this direction.

In addition to the plants and problems mentioned above, it is also of interest to note that we have under consideration the following problems, upon which varying amounts of progress have already been made: These include the collection of

Aluminum oxide

Powdered starch

Powdered sugar

Powdered coal

Tin oxide for enamel

Powdered sulphur

Potash from burning of molasses

Potash from cotton seed hulls 
Black smoke from round houses and other places

Fertilizer dusts

Zinc sulphides

Zinc oxides

Powdered borax

Fumes and dust from calcium carbide furnaces

Dust from rotary lime kilns

Dust from pyrite burners in sulphuric acid plants

Gold and silver from jewellers' sweepings

Fumes from linseed oil boiling kettles in varnish works

Powdered alundum

Ammonium chloride

Nitric acid, etc.

Inquiries have been recieved on many other problems but the above statements show that the electrical processes are applicable to a great variety of materials and conditions, especially when it is also considered that the range of operating temperatures is from a point at least as low as zero cent. to at least as high as 600 deg. cent., and at all temperatures between these two limits. Materials can be selected for each specific problem which will withstand the local conditions as regards temperature, corrosion, mechanical strength, expense, etc.

In addition to collection of materials, because of nuisance or of value of the suspended matter, it is worth noting that the processes are useful as adjuncts to other manufacturing processes or methods, either for improving operations or reducing expense. Both the lead-chamber process and the contact processes of producing sulphuric acid have several places in which the electrical processes should be valuable. The use of the electrical processes in conjunction with ventilation of the railroad tunnels in Baltimore is also under consideration and they may be installed there unless electrification of the railroads is decided upon, in which event, of course, there will be no smoke to precipitate. Furthermore, since it is so easy to remove dust from air by these processes, they may be useful in connection with the ever-present problem of suitably ventilating subways.

It should be apparent that contact with such a variety of actual industrial problems as has been mentioned would furnish an impetus to improving and simplifying treaters and the electrical apparatus, and to call forth a goodly number of patentable discoveries. While this is true, yet the policy has been not to overlook those mechanical and other operating features 
which would insure reliability of operation primarily and reduce cost of installation, maintenance and operation, as well as to make the processes as nearly automatic in operation as possible. Efforts along these lines were also accompanied by efforts toward standardization of types and sizes of treaters, of electrical equipment including switchboard panels, and to adopting schemes or plans that would facilitate and expedite the collection of data, conducting of experimental tests, and, finally, the completion of commercially and technically satisfactory installations.

The use of sphere spark gaps for the measurement of peak voltages between the discharge and grounded electrodes, and in other parts of the circuit has led to a better understanding of occurring electric phenomena. For these measurements a convenient portable sphere spark gap, as shown in Fig. 24 has been developed. Additional data on electric phenomena have been obtained by the study of the effect, under various conditions, of especially designed inductances placed in the high tension circuit. Methods have been devised whereby it is possible to predict quite closely the power required for the treatment of a specified quantity of a given gas. The power required for treaters is sufficiently low as not to be prohibitive in practically all cases where it is desirable to remove fine particles from gases. Power factors above 80 per cent are commonly found in the supply circuits. Actual power consumptions of installations now in operation will be found in the descriptions of some of the various plants given above. "Laboratory instruments" are in general too delicate for use in the field and "standard apparatus" often has failed to give satisfactory results until modified to suit the special requirements.

Improvements have been made in rectifiers and the method of using them. Some are now being operated commercially at 750 rev. per min., which speed presents some advantages over the former speed of $1800 \mathrm{rev}$. per min.

Transformer designs have been evolved which give apparatus very suitable for our work. Their reliability has been improved and the cost and time of delivery have been materially reduced. Apparatus has been developed to automatically restore normal operation after a temporary short circuit in the treater due to conductive precipitated material falling between the opposed electrodes, or to similar temporary overloads resulting from 
PLATE XXXI.

A. I. E. E.

VOL. $X X X I V$, NO. 4

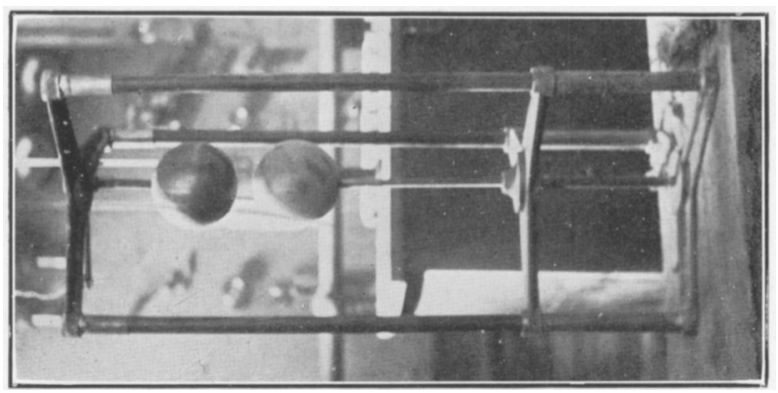

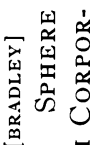

(工) I

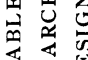

近结 되

홍 되

요 의

1 $\left.\right|_{4} \underset{4}{\Theta}$

त 0

.

ن

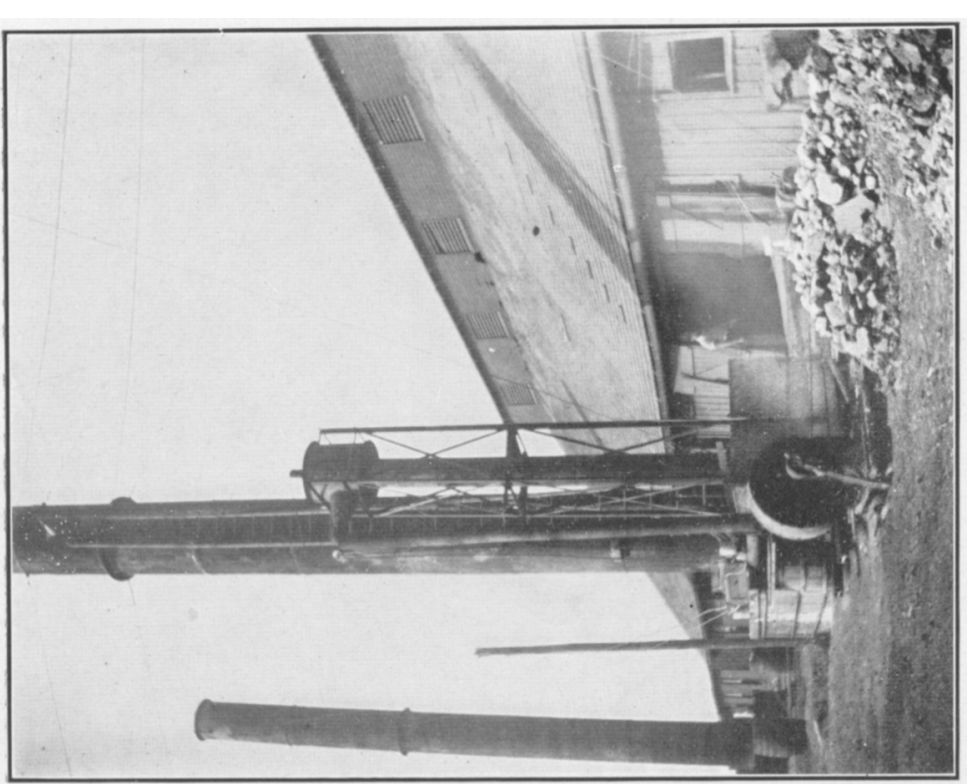

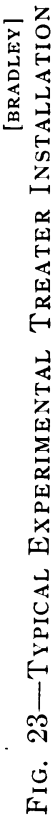



unusual conditions. Improvements have been made in the manner of introducing the high potential line into the treater and along with these, improved methods of supporting and insulating the discharge electrodes have been developed. Durable discharge electrodes have been developed, thus overcoming the reasonable objections to the use of small wires in corrosive gases.

The typical curve shown in Fig. 25 gives the relationship between the high-tension direct current flowing into the treater and the high-tension voltage impressed upon it, the latter being

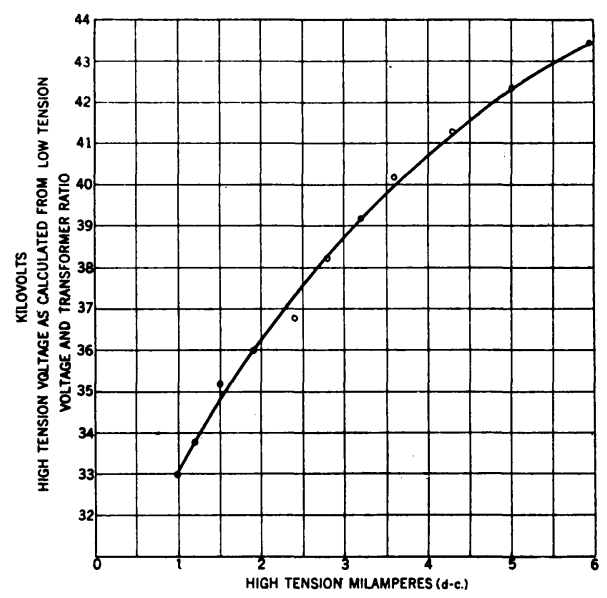

Fig. 25-Curve Showing Ratio of High Tension Voltage to the Current Consumption-The Measurement taken at Treater Installed for Balbach Smelting and Refining Company, NewARK, N. J.

shown on the curve sheet as the alternating potential delivered to the rectifier from the transformer and calculated from the measured low-tension voltage and the transformer ratio. Under certain conditions it would be preferable to measure the effective high-tension voltage maintained between the treater electrodes by means of a suitable voltmeter. In general, however, the voltage as indicated by the ratio method is sufficiently accurate for field work. The lower portion of the curve shows the uniform increase in the current with the voltage, due chiefly to insulator leakage. The upper portion of the curve shows the more rapid increase in the current as the voltage is raised above 
that at which corona started. The bend in this particular curve is somewhat more gradual than is usually found. This is due to a special arrangement of the electrodes whereby the corona starting voltage varies in different parts of the treater.

Fig. 26 shows the results obtained from tests made with various electrode spacings in fume-laden gases at different temperatures. Curve A shows the potential (measured by transformer ratio and the low-tension voltage) which, when rectified, caused a spark-over to occur between a number of parallel wires and a plate placed at varying distances from them.

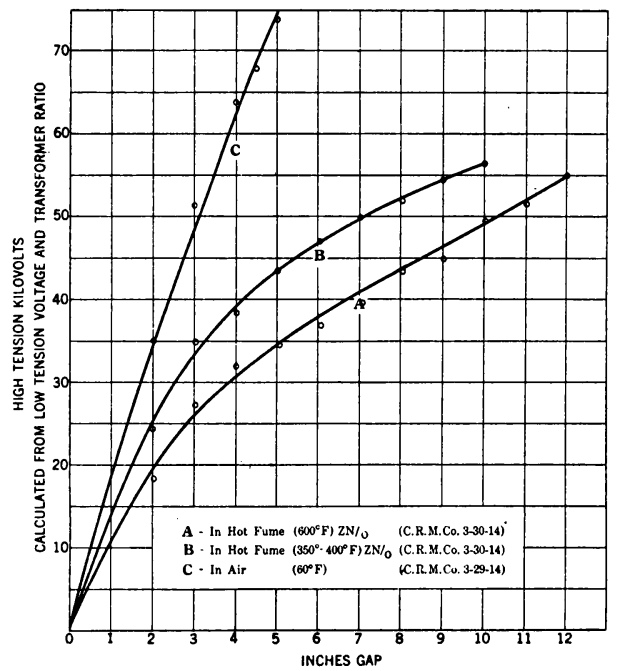

Fig. 26-Curves Showing Sparking Potentials (of Rectified Voltages) between Wires and a Parallel Plate, for Various Gap SPACINGS

The wires and plates were placed in a flue through which passed zinc oxide fumes at a temperature of $600 \mathrm{deg}$. fahr. Curve $B$ shows similar data obtained with the gas temperature reduced to between $350 \mathrm{deg}$. and $400 \mathrm{deg}$. fahr. Curve $C$ shows similar data obtained from the same electrode system with air in the flue. The relative positions of curves $A$ and $B$ are what would be expected. Data are being obtained in order to plot a series of curves between corona starting voltage (ratio method) and electrode spacings. This work has not been completed.

Fig. 27 gives in a specific case the distribution of the electrical losses in transformation, rectification and transmission 
of the electrical power taken from the supply lines and delivered to the treater. Those of transformation (from 220 volts lowtension) are the greatest. The additional load losses of the transformer are readily calculated. The added load losses of the rectifier are not definitely known but experience indicates that they are small in proportion to the other losses. The added load losses of the transmission line are negligible. These latter losses consist almost entirely of corona loss and insulator leakage both of which depend upon the voltage and not upon the current. From such data it is possible to estimate very closely, the capacity of apparatus required to deliver to the treater any given power at a certain voltage.

As for the actual treaters or chambers in which electrodes

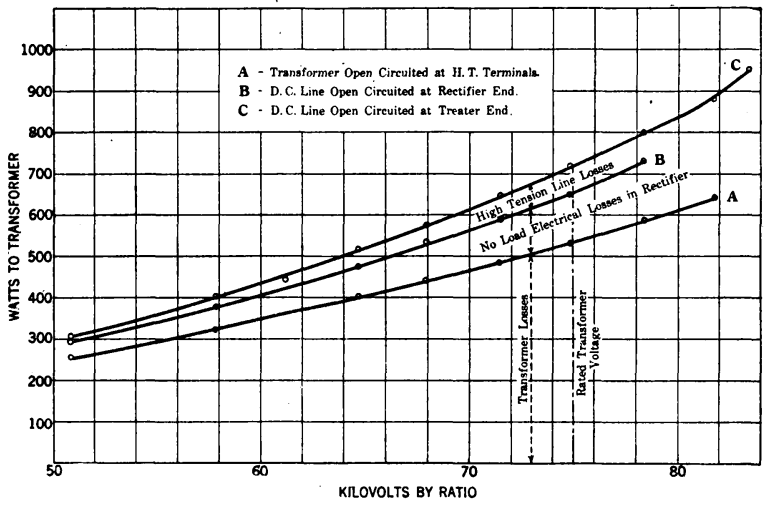

Fig. 27-Power Loss Data

Transformer $7 \frac{k v-a .}{75,000-v . ~} 60 \sim$. Rectifier type -2 arm-8 shoe-steel shaft. Line insulators 2 per line trans. to rect., 11 in d-c. line.

are installed, several types and sizes have been standardized. These are for widely varying gas conditions. Valuable experience has been had on friction loss of gases passing through treaters, and through inlets and outlets, and on getting uniform gas distribution. The latter is more difficult to control when the velocity of the gas is low than when it is high. Treater construction costs have been greatly decreased.

Valuable experience has been had in the field of measuring and sampling large volumes of moving gases, and methods suitable for our work have been evolved which have been proved of practical reliability by results on large scale installations. Several complex. flue systems and stacks have been explored and data obtained in such a manner that reliable predictions 
were possible, as to the effect of the installation of electrical precipitation equipment. In many cases this is a very pertinent question, especially when natural draft is depended upon to move the gases.

TABLE II

Experimental Data on 2-Treater Sections of Twenty 14-in. Diam. Pipes Each. SiNGLE Wire Electrode

\begin{tabular}{|c|c|c|c|c|c|c|c|c|c|}
\hline Time & Tap* & $\begin{array}{l}\text { Volts } \\
\text { low- } \\
\text { tension }\end{array}$ & $\begin{array}{c}\text { Kilo } \\
\text { volts } \\
\text { high- } \\
\text { tension } \\
\text { by ratio }\end{array}$ & $\begin{array}{c}\text { Amps } \\
\text { low- } \\
\text { tension }\end{array}$ & $\begin{array}{c}\text { Watts } \\
\text { cor- } \\
\text { rected }\end{array}$ & $\begin{array}{l}\text { Volt- } \\
\text { amps. }\end{array}$ & $\begin{array}{l}\text { Power } \\
\text { factor }\end{array}$ & $\begin{array}{c}\text { Fan } \\
\text { speed. }\end{array}$ & $\begin{array}{c}\text { Differ- } \\
\text { ence in } \\
\text { static } \\
\text { Fan in- } \\
\text { let \& } \\
\text { outlet } \\
\text { in oz .per } \\
\text { sq. in. }\end{array}$ \\
\hline $\begin{array}{r}\text { P.M. } \\
4: 30\end{array}$ & & & & Run & Started. & & & & \\
\hline 5:00 & 5 & 182 & 57.0 & 15 & 2100 & 2730 & 0.76 & 330 & $1 \frac{1}{6}$ \\
\hline $5: 30$ & 4 & 170 & 64.0 & 25 & 3500 & 4250 & 0.82 & 323 & 13 \\
\hline $6: 00$ & 4 & 165 & 62.0 & 20 & 2550 & 3300 & 0.77 & 331 & $1\} t$ \\
\hline $6: 30$ & 4 & 175 & 65.7 & 16 & 2400 & 2800 & 0.85 & $\ldots$ & $\ldots$ \\
\hline $7: 00$ & 4 & 172 & 64.7 & 17 & 2500 & 2924 & 0.85 & 320 & 1 \\
\hline $8: 40$ & \multicolumn{9}{|c|}{ Both sections cleaned pipes and wires. } \\
\hline $8: 45$ & 5 & 185 & 58.0 & 13 & 2000 & 2400 & 0.83 & 325 & $1\}$ \\
\hline $9: 15$ & 5 & 194 & 60.5 & 10 & 1500 & $\cdot 1940$ & 0.77 & 320 & 1 \\
\hline $9: 40$ & \multicolumn{9}{|c|}{ Pipes rapped section No. 2 shut down for $1 \mathrm{~min}$. } \\
\hline $9: 45$ & 5 & 195 & 61.0 & 10 & 1350 & 1950 & .69 & 301 & 1 \\
\hline \multicolumn{10}{|c|}{$\begin{array}{l}\text { Readings continued about as above at half hour intervals and pipes cleaned by ham- } \\
\text { mering every hour until } 4: 00 \mathrm{a} . \mathrm{m} \text {. }\end{array}$} \\
\hline A.M. & & & & & & & & & \\
\hline 4:00 & 5 & 195 & 61.0 & 10 & 1350 & 1950 & 0.69 & 285 & t \\
\hline $4: 25$ & & Pipes & rapped. & & & & & & \\
\hline $4: 30$ & 5 & 200 & 62.5 & 8 & 1150 & 1600 & 0.72 & 292 & t† \\
\hline $5: 00$ & 5 & 200 & 62.5 & 8 & 1250 & 1600 & 0.78 & 268 & t \\
\hline $5: 35$ & 5 & 200 & 62.5 & 12 & 1800 & 2400 & 0.75 & 270 & $\frac{3}{2}$ \\
\hline $6: 00$ & 5 & 205 & 64.0 & 8 & 1200 & 1640 & 0.73 & 277 & 4 \\
\hline $6: 30$ & 5 & 200 & 62.5 & 6 & 1000 & 1200 & 0.83 & 270 & $t$ \\
\hline $7: 00$ & 5 & 197 & 61.5 & 6 & 1050 & 1180 & 0.89 & 276 & I \\
\hline $7: 30$ & 5 & 200 & 62.5 & 9 & 1150 & 1800 & 0.64 & 273 & t \\
\hline $8: 20$ & 5 & 202 & 63.0 & 8 & 1000 & 1620 & 0.62 & 278 & 1 \\
\hline $8: 30$ & & Run dis & continued & & & & & & \\
\hline
\end{tabular}

* Transformer Ratio Tap 4-200 to 75,000 volts.

$†$ Pipes rapped $5-200$ to 62,500

$\ddagger$ Pipes rapped at $5: 20$

The log sheet shown in Table II gives a typical set of readings taken during a run on a two-section treater. Each section consists of twenty 12-in. diameter pipes, $12 \mathrm{ft}$. long. The log sheet shows a considerable variation of the power consumption 


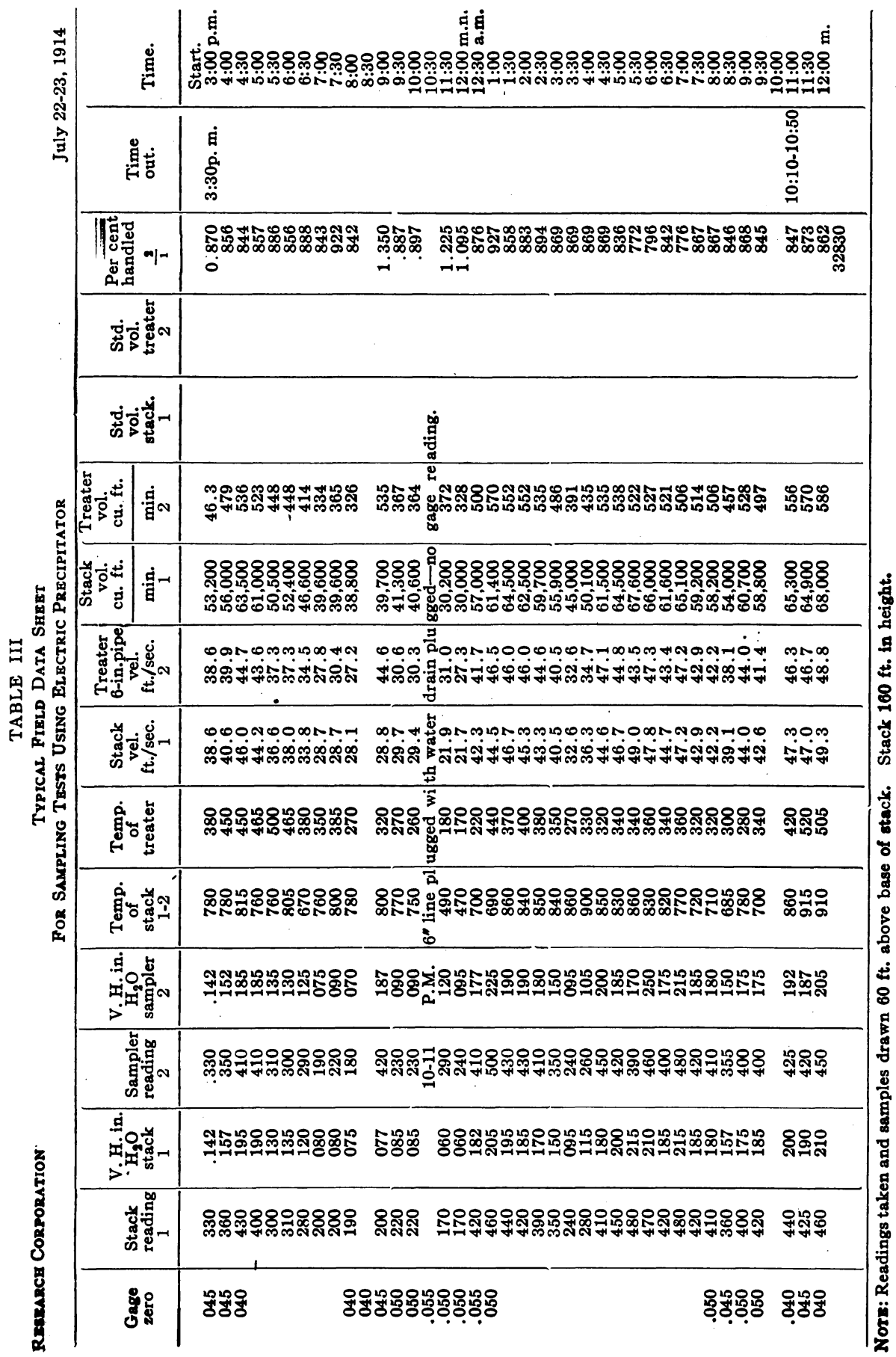


and of power factor. This was one of the first test runs made in application of the electrical processes to a new problem. Causes for each unsteady or unfavorable condition are sought and the effect of each on the percentage of precipitation is noted and steps are taken toward their elimination. Finally with the proper conditions secured, the operation becomes steady and automatic. Electrical data and gas measurements are taken simultaneously.

A typical field data sheet is given in Table III. It was used in connection with flue loss determinations, and is a copy of actual test data obtained in a 24-hour test. (See Fig. 28 for arrange-

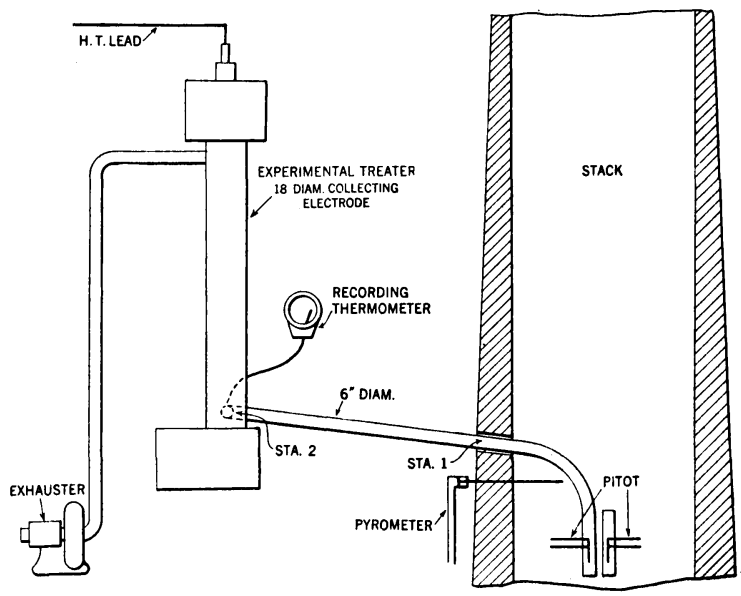

FIG. 28

ment). From left to right the columns shown give the following information:

Column 1. Gage zero-on the differential gage used; a zero reading was always taken.

Column 2. Stack reading-a differential gage reading, indicating the gas velocities in the stack. The gage is connected to a pitot tube in a 6-inch diam. "companion" pipe shown in Fig. 28.

- 3. V.H. in. $\mathrm{H}_{2} \mathrm{O}$ Stack -is the gas velocity head in inches $\mathrm{H}_{2} \mathrm{O}$ in the stack and is one-half the difference between columns 1 and 2 . (Gage factor $=0.5$ )

“ 4. Sampler Reading-is the reading indicated on the differential gage, connected to the pitot tube in the 6 in. dia. sampler pipe. (See Fig. 28).

" 5. V.H. in. $\mathrm{H}_{2} \mathrm{O}$ sampler-is the gas velocity heads in inches $\mathrm{H}_{2} \mathrm{O}$ in the 6-inch dia. sampler pipe. (Gage factor $=0.5$ ). 
Column 6. Temperature of stack gases in degrees fahrenheit.
“ 7.
a
" Gases in treater in degrees fahrenheit.

a 8. Stack Vel. ft. per sec.-velocity of gases in stack.

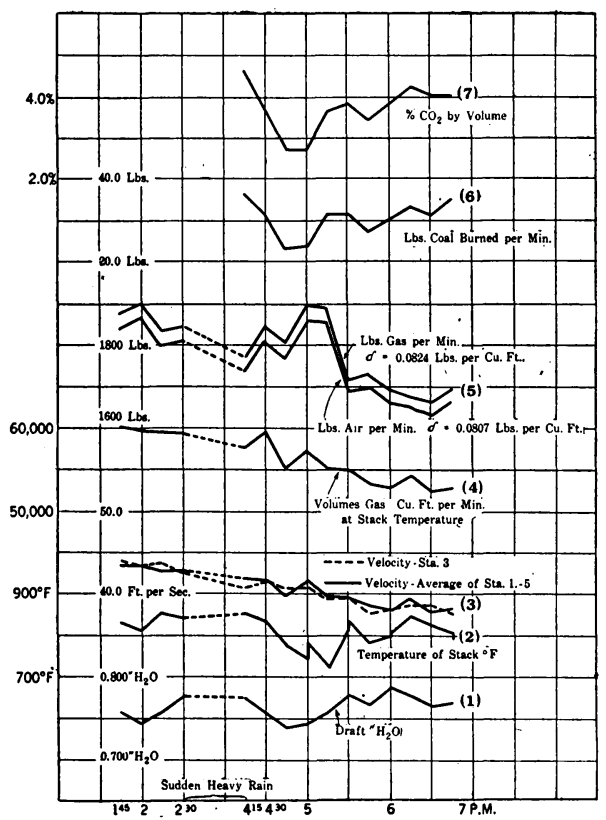

FIG. 29

Weather generally fair-Barometer 29.47 in. $\mathrm{Hg}$.

Elevation of station $440+65=505 \mathrm{ft}$. A. S. L.

Barometer correction for velocity;

$\mathrm{V}$ from chart. $\times 1.008=\mathrm{V}$ actual.

Correction for carbon dioxide;

$\mathrm{V}$ from chart $\times 0.990=\mathrm{V}$ actual $(4$ per cent $\mathrm{CO}_{2}$ )

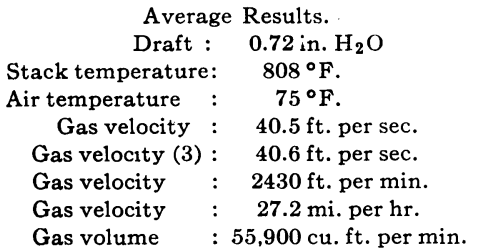

Gas weight $\quad: 1745$ lb.per min. (air) weight : $1780 \mathrm{lb}$. per min.(gas) Standard volume : $21,600 \mathrm{cu} . \mathrm{ft}$. per min. $\mathrm{CO}_{2} \%$ by volume : 3.67 per cent. Lb. carbon: 26.6 burned per min Lb. coal : 30.6 burned per min Scale

Horizontal:

1 division $=1$ hour

Vertical :

0.1 division $=0.02$ in. $\mathrm{H}_{2} \mathrm{O}$ draft. (1)

$=20^{\circ} \mathrm{F}$, stack temperature.

$=1.0 \mathrm{ft}$. per sec.

(2)

$=1000 \mathrm{cu} . \mathrm{ft}$. per $\min .(4)$

$=20.0 \mathrm{lb}$. per min. gas (5)

$=0.2$ per cent $\mathrm{CO}_{2}$

$=2 \mathrm{lb}$. coal

Column 9. Treater 6-inch Pipe Vel. ft. per sec.-velocity of gases in 6-in. diam. sampler pipe to treater.

“ 10. Stack Vol. cu. ft. per min.-volume of stack gases per minute.

“ 11. Treater Vol. cu. ft. per min.-volume of treater gases per minute. 
Column 12. Std. Vol. Stack-volume of stack gases at 32 deg. fahr., 29.92 in. $\mathrm{H}_{\mathrm{g}}$.

13. Std. Treater Vol.-Volume of treater gases at 32 deg. fahr., 29.92 in. $\mathrm{H}_{\mathrm{g}}$.

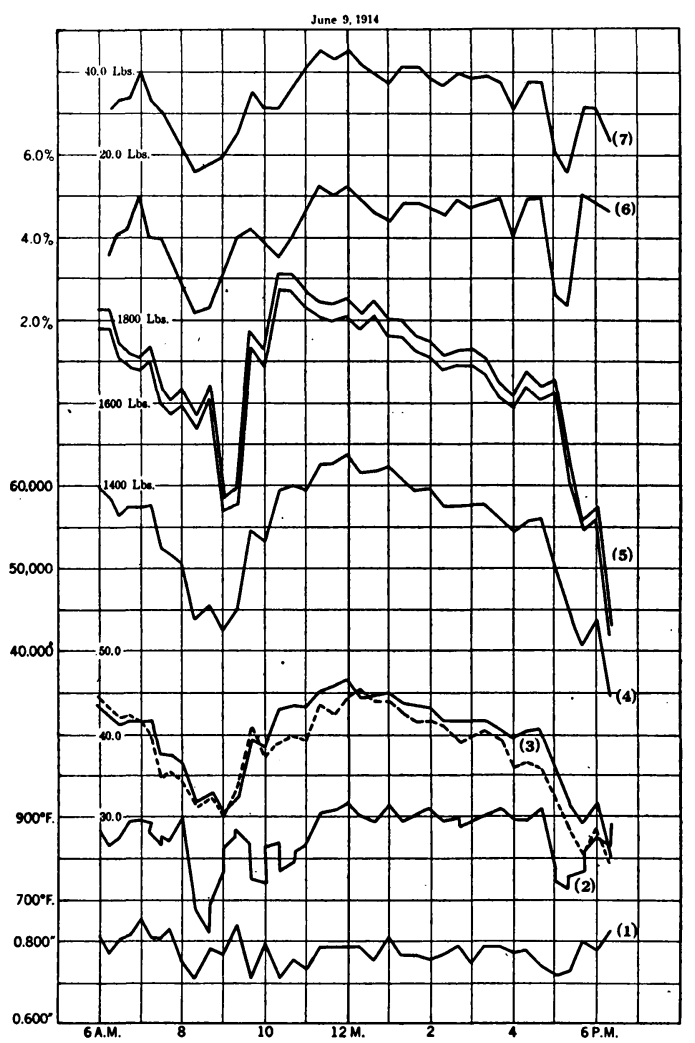

FIG. 30

Scale

Abscissa: 1 division $=2$ hours

Ordinate:

(1) 0.1 division $=0.02$ in. $\mathrm{H}_{2} \mathrm{O}$ draft

(2) $\quad=20^{\circ} \mathrm{F}$. stack temp.

(3) $\quad=1.0 \mathrm{ft}$. per sec. gas velocity

(4) = $1000 \mathrm{cu}$. ft. per min. gas volume

(5) $=20 \mathrm{lb}$. per min. gas weight

(6) $\quad=0.2$ per cent $\mathrm{CO}_{2}$ by vol.

(7) $\quad=20 \mathrm{lb}$. per min. coal burned.

Column 14. Per cent handled-ratio of gases handled in precipitator to total gases in stack.

" 15. Time Out-record of "shut downs" or troubles incidental to the test.

a 16. Time-schedule of readings taken during test. 
PLATE XXXV.

A. I. E. E.

VOL. XXXIV, NO 4

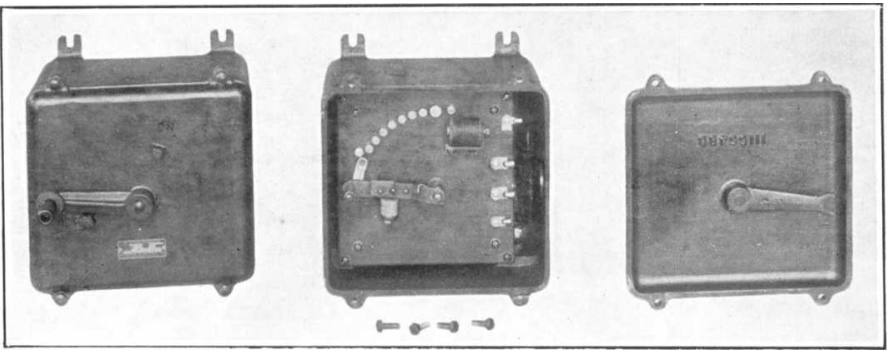

[MCLAIN]

Fig. 1-Completely Enclosed Hand Starter for Direct-Current MOTORS

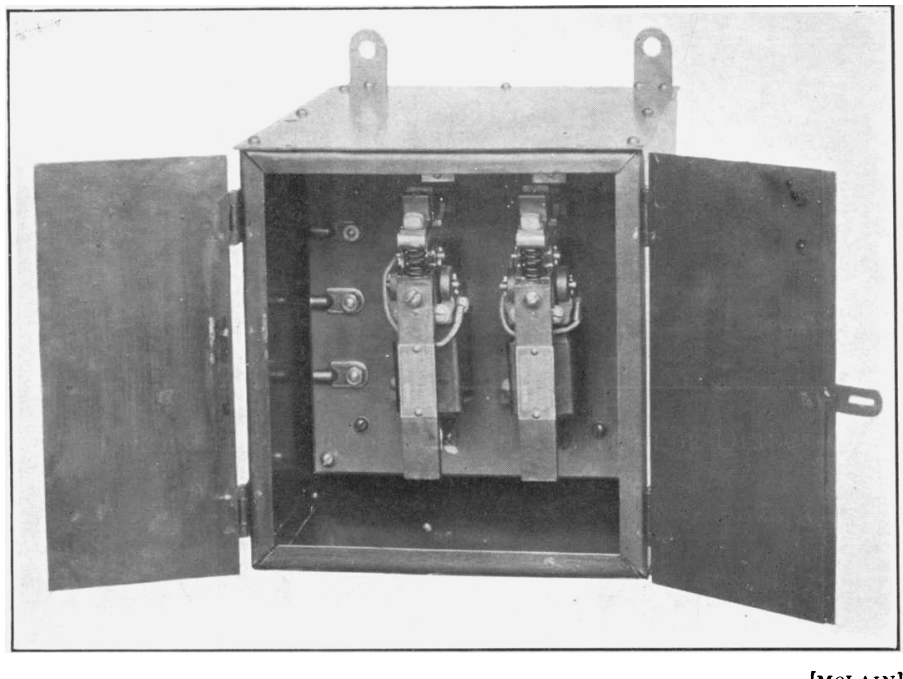

Fig. 2-Three-Point Automatic Starter with Sheet Iron Enclosing Case for Direct-Current Motors 

In connection with the above data, sets of daily measurements were made of the quantities and conditions of the gases in the stack. The detail of these figures is given in the form

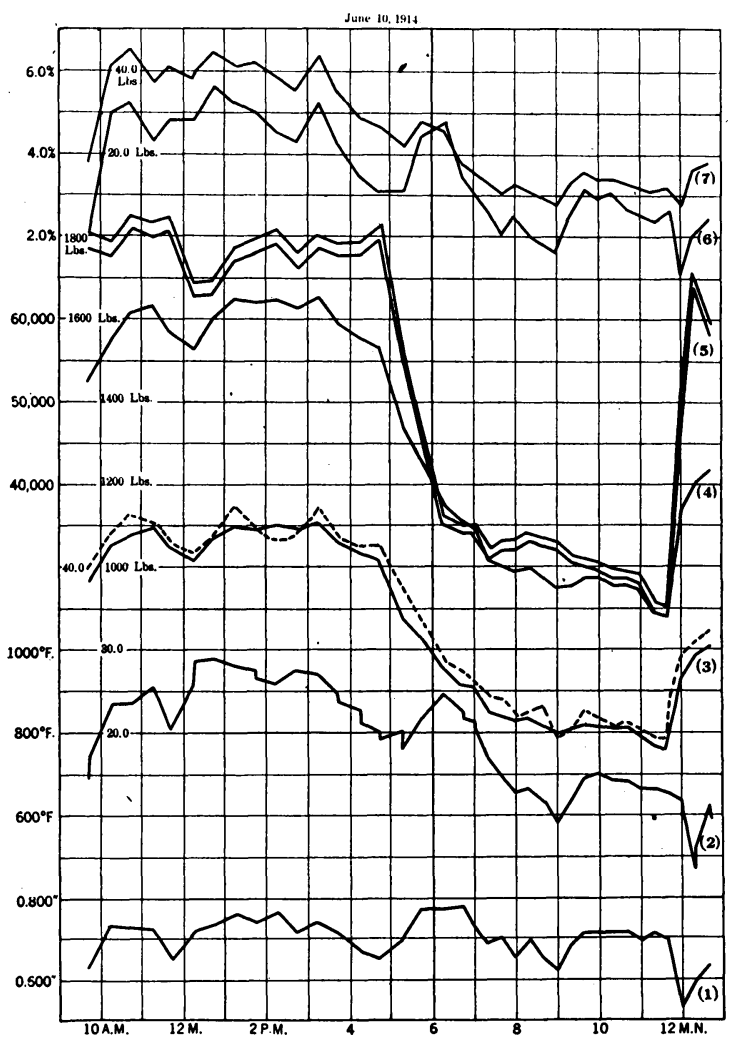

FIG. 31

Scale

Abscissa: 1 division $=2$ hours Ordinate:

(1) 0.1 division $=0.02$ in. $\mathrm{H}_{2} \mathrm{O}$ draft

(2)

(3)

(4)

(5)

(6)

(7)

$=20^{\circ} \mathrm{F}$. stack temp.

$=1.0 \mathrm{ft}$. per sec. gas velocity

$=1000 \mathrm{cu} . \mathrm{ft}$. per min. gas volume

$=20 \mathrm{lb}$. per min. gas weight

$=0.2$ per cent $\mathrm{CO}_{2}$ by vol.

$=20 \mathrm{lb}$. per min coal burned.

of "curve sheets" as Figs. 29, 30, 31 and 32 . These results are summarized in Table IV.

Temperature records kept during the above mentioned test are given as Figs. 33 and 34. 
In Fig. 35 a sketch of the electric precipitator used for the demonstration in connection with this paper is shown. This sketch includes the method of showing corona effects and the

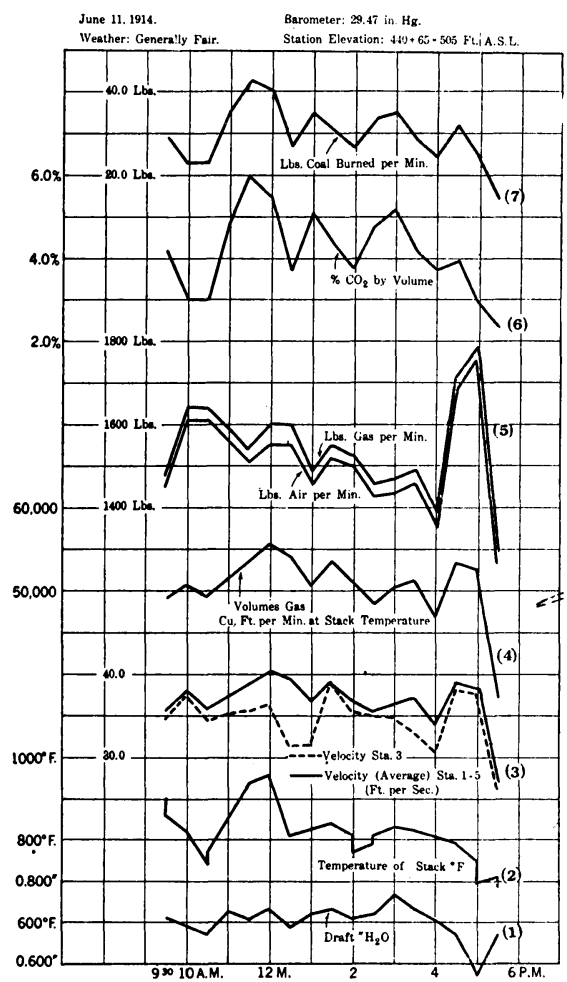

FIG. 32

\section{Scale}

Abscissa: 1 division $=2$ hours.

Ordinate:

(1) 0.1 'division $=0.02$ in. $\mathrm{H}_{2} \mathrm{O}$ draft.

(2) $\quad=20^{\circ} \mathrm{F}$. (stack)

(3) $=1.0 \mathrm{ft}$. per sec.

(4) $=1000 \mathrm{cu} . \mathrm{ft}$. per min.

(5) $\quad=20 \mathrm{lb}$. per $\min$. (gas)

(6) $\quad=0.2$ per cent $\mathrm{CO}_{2}$

(7) $=2 \mathrm{lb}$. coal per $\min$.
$\begin{array}{ll}0.700 \text { in. } \mathrm{H}_{2} \mathrm{O} & \text { Results } \\ \text { average draft }\end{array}$ $870^{\circ} \mathrm{F}$. average stack temp. $84^{\circ} \mathrm{F}$. average air temp. $36.7 \quad$ average gas velocity

Sta. No. 3 centeraveragegas velocity 34.4 $2200 \mathrm{ft}$. per min.average gas velocity. $25.0 \mathrm{mi}$. per hr.average gas velocity. $50,700 \quad$ average gas volume 1520 average gas wt. (air) 1550 average gas wt. (gas) 18,800 average std. volume 4.17 average $\% \mathrm{CO}_{2}$ by volume 26.2 average lb. carbon 30.1 average lb. coal

method of producing fume and dust for precipitation, in connection with the experiments prepared for this demonstration.

Several additional installations of these processes have been 
made under the direction of Mr. Walter A. Schmidt, of Los Angeles, California, at various locations in the Pacific Coast States, Canada, and Germany. The one which treats the largest volume of gases is at the plant of the Riverside Portland Cement Company. The installation at the Smelter near Trail, B. C. treats about 100,000 cu. ft. of gases per minute coming

TABLE IV

Elevation of Station 505 Ft. A. S. L. Barometer 29.47 in Hg. Top of Stack -505 ft. A. S. L. Stack Height-160 Ft.

\begin{tabular}{|c|c|c|c|c|c|c|c|}
\hline & 1 & 2 & 3 & 4 & 5 & 6 & 7 \\
\hline Date & $\begin{array}{l}\text { Day } \\
\text { June } \\
8-14\end{array}$ & $\begin{array}{l}\text { Day } \\
\text { June } \\
9-14\end{array}$ & $\begin{array}{l}\text { Day } \\
\text { June } \\
9-14\end{array}$ & $\begin{array}{c}\text { Average } \\
2 \& 3\end{array}$ & $\begin{array}{c}\text { Day } \\
\text { June } \\
10-14\end{array}$ & $\begin{array}{c}\text { Night } \\
\text { June } \\
10-14\end{array}$ & $\begin{array}{c}\text { Day } \\
\text { June } \\
11-14\end{array}$ \\
\hline Period of Measurement. & $\begin{array}{c}1: 45 \text { p.m. } \\
\text { to2:30 “ } \\
4: 15 \text { " } \\
\text { to } \\
6: 45 \text { " }\end{array}$ & $\begin{array}{l}6 \text { a.m. to } \\
12 \mathrm{~m} .\end{array}$ & $\begin{array}{l}12: 20 \text { to } \\
6: 20 \mathrm{pm} .\end{array}$ & & $\begin{array}{l}9: 45 \text { A.m } \\
5: 45 \mathrm{pm} .\end{array}$ & $\begin{array}{l}6: 45 \mathrm{pm} \\
12: 40 \\
\text { a. } \mathrm{m} .\end{array}$ & $\begin{array}{l}.9: 30 \mathrm{am} \\
5: 30 \mathrm{pm}\end{array}$ \\
\hline $\mid \begin{array}{c}\text { Velocity of gas feet per } \\
\text { sec. . } \ldots \ldots \ldots \ldots \ldots \ldots \\
\text { Velocity of gas. }\end{array}$ & 40.5 & .42 .1 & 39.3 & 40.7 & 41.7 & 21.7 & 36.7 \\
\hline Feet/minute. & 2430 & 2520 & 2360 & 2440 & 2520 & 1320 & 2220 \\
\hline Miles/hour... & 27.2 & 28.6 & 26.6 & 27.6 & 28.6 & 15.0 & 25.2 \\
\hline $\begin{array}{l}\text { Flue temperature }{ }^{\circ} \mathrm{F} \ldots \\
\text { Volume of gascu. } \mathrm{ft} / \mathrm{min}\end{array}$ & 810 & 830 & 880 & 855 & 870 & 690 & 870 \\
\hline $\begin{array}{l}\text { @ flue temperature... } \\
\text { Volume of gas.cu. } \mathrm{tt} / \mathrm{min}\end{array}$ & 55,900 & 58,100 & 54,300 & 56,200 & 58,000 & 30,200 & 51,000 \\
\hline at $29.92^{\prime \prime} \mathrm{Hg} .32^{\circ} \mathrm{F} \ldots \ldots$ & 21,600 & 22,150 & 19,900 & 21,050 & 21,450 & 12,900 & 18,900 \\
\hline Weight of gas passing & Air .1745 & 1790 & 1610 & 1700 & 1730 & 1040 & 1525 \\
\hline lbs $\min . \ldots \ldots \ldots \ldots$ & Gas 1780 & 1825 & 1640 & 1735 & 1765 & 1060 & 1555 \\
\hline $\mid \begin{array}{l}\% \mathrm{Co}_{2} \text { by vol. } \ldots \ldots \\
\text { Calculated } 1 \mathrm{~b} .\end{array}$ & 3.67 & 4.00 & 4.47 & 4.24 & 4.36 & 2.12 & 4.17 \\
\hline burned per minute... & 26.6 & 29.6 & 29.7 & 29.65 & 31.3 & 9.12 & 26.2 \\
\hline $\begin{array}{c}\text { Calculated lb. coal } \\
\text { burned per minute... }\end{array}$ & 30.6 & 34.1 & 34.2 & 34.15 & 36.0 & 10.5 & 30.4 \\
\hline $\begin{array}{l}\text { Stack draft inches } \mathrm{H}_{2} \mathrm{O} \\
\text { Sets of fires. . . . . . . }\end{array}$ & $\begin{array}{r}0.720 \\
1-8\end{array}$ & $\begin{array}{r}0.781 \\
1-8\end{array}$ & $\begin{array}{r}0.775 \\
1-8\end{array}$ & $\begin{array}{r}0.778 \\
1-8\end{array}$ & $\begin{array}{r}0.712 \\
1-8\end{array}$ & $\begin{array}{r}0.692 \\
1-4\end{array}$ & $\begin{array}{r}0.700 \\
1-7\end{array}$ \\
\hline No. of fires.... & 88 & $\begin{array}{r}1-0 \\
88\end{array}$ & $\begin{array}{r}1-0 \\
88\end{array}$ & 88 & $\begin{array}{r}1-0 \\
88\end{array}$ & $\begin{array}{r}1-4 \\
48\end{array}$ & 78 \\
\hline Air temp. ${ }^{\circ} \mathrm{F} . \ldots \ldots \ldots$ & 75 & 61 & 67 & 64 & 80 & 77 & 84 \\
\hline
\end{tabular}

from lead blast furnaces. A treater has been installed for handling the gases from one 1000-barrel cement kiln at Buffington, Indiana, and a continuous thirty day test showed an average of approximately 95 per cent of the dust removed from between 60,000 and $75,000 \mathrm{cu}$. ft. of gas per minute, the temperature occasionally reaching $750 \mathrm{deg}$. cent.

In conclusion it is to be stated that the past three years have 


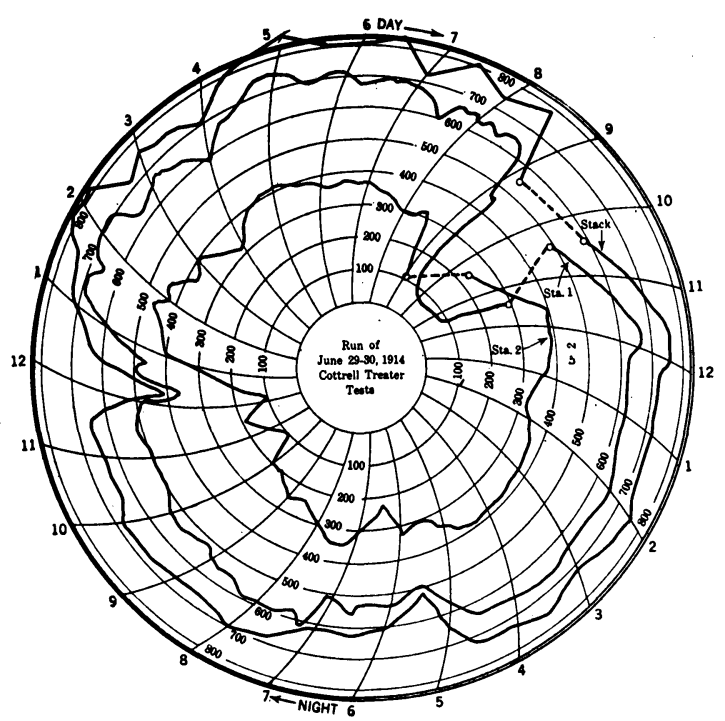

Fig. 33-Temperature Records in Connection with electric PreCIPITATOR TESTS

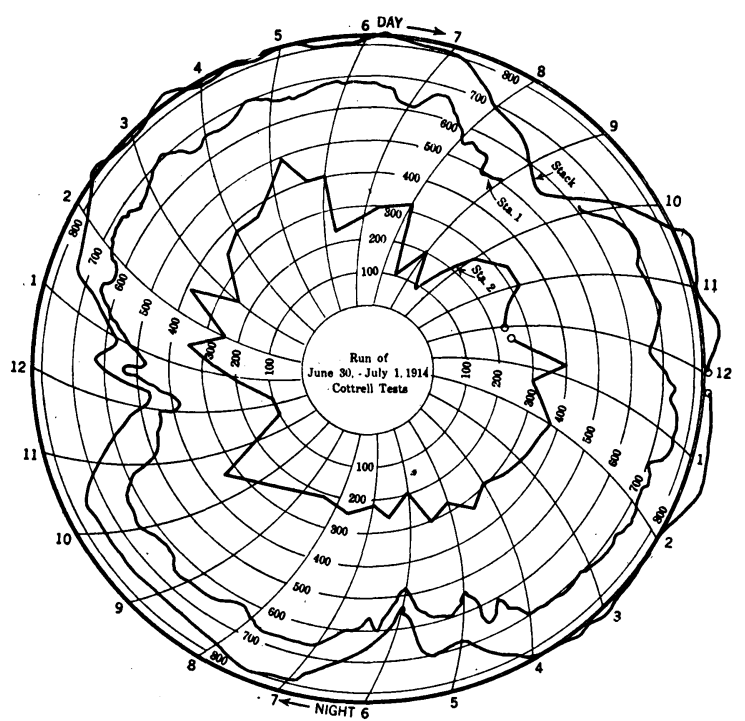

Fig. 34-Temperature Records in Connection with Electric PreCIPITATOR TESTS 
seen the electrical processes (Cottrell patents) in constantly growing use and demand, several commercial installations having produced excellent results, and that the future is full of promise. The corporation has definitely established itself commercially in the short time intervening since its organization. The total capital paid into the treasury was $\$ 10,100$. From the receipts so far obtained for technical services and for patent rights, all the corporation's stockholders have been fully repaid, and there is on hand at present nearly $\$ 150,000$ in good and

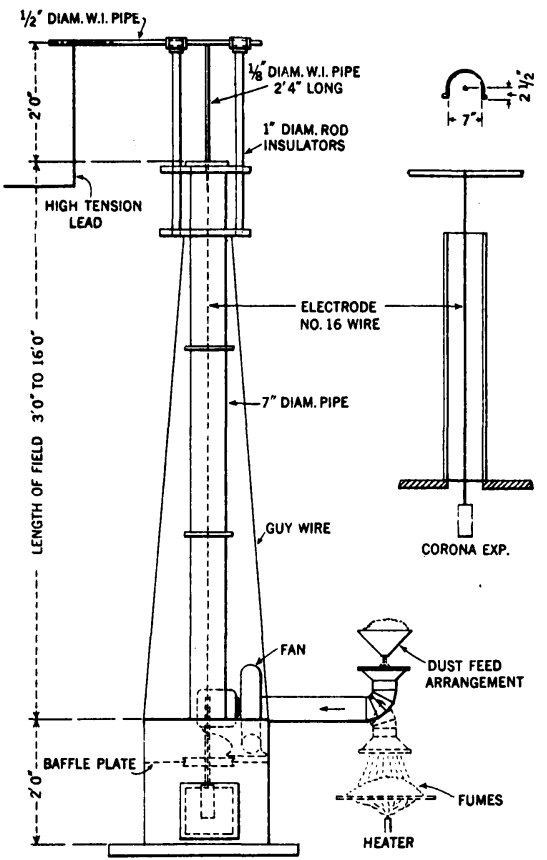

Fig. 35-Demonstration Treater

negotiable securities as a net surplus, with only ordinary current accounts owing. Further income as royalties from installations now in operation, under way, or contracted for, will materially increase the above amount, so that a fund for further scientific research has already been created, and this directly from the industries benefited by the processes administered by the corporation.

Surely the record of the results obtained, both those technical and commercial, and the indications observable from direct 
personal contact with the ever-growing and widening field, and the actual inquiries received, warrant and justify the statement that the electrical processes and the movement represented in the Research Corporation have been definitely established and that the future holds vastly more of promise than the past.

Messrs. H. D. Egbert, P. E. Landolt, A. F. Meston, C. I. Weir, J. C. Hale, H. A. Burns, H. M. Pier, assistant engineers in the employ of the corporation have rendered very valuable service in connection with the various problems which have been encountered and have materially aided in overcoming the many difficulties. They have been very loyal and devoted to the cause, working in the main under very unfavorable conditions and receiving smaller compensation during most of the three years the corporation has been operating than they could have obtained elsewhere, and they are to be complimented and thanked for their zealous and efficient service. The technical men in the various plants have likewise taken a keen interest in the work and have rendered valuable services and have been of great assistance in enabling the presentation of a report of such progress and thanks are due them.

\section{SELECTED BIBLIOGRAPHY}

\section{F. G. Cottrell.}

"The Electrical Precipitation of Suspended Particles," Jour. Ind. \& Eng. Chem. vol. 3, 542-550 Aug. 1911. "Electric Fume Precipitation" Trans. Amer. Instit. Mining Eng. Vol. 43, 512-520, 755-762 N. Y. Meeting Feb. 1912. "The Research Corporation, an experiment in Public Administration of Patent Rights." ' Reprint of the 8th Inter. Congress of Applied Chemistry Vol. 24, 59-69 Sept. 1912. The same reprinted in Jour. Ind. \& Eng. Chem. Dec. 1912, 864-867, Vol. 4. Problems in Smoke, Fume and Dust Abatement, Smithsonian Report for 1913, pages 653-685.

\section{Linn Bradley.}

"Electrical Precipitation of Suspended Particles." Reprint from 8th Intern. Congress of Applied Chemistry, Sept. 1912. Jour. Ind. \& Eng. Chem. vol. 22, pp. 489-497, 1912. Trans. Amer. Electrochem. also Met. \& Chem. Eng. "Precipitation of Suspended Particles." Proceedings Eng. Soc. of Western Penn. Vol. 29 No. 3, Apr. 1913.

Walter A. Schmidt.

"The Control of Dust in Portland Cement Manufacture by Cottrell Precipitation Processes." Reprint 8th International Congress Applied Chemistry; Vol. 5, 117-124, 1912. Journ. Ind. \& Eng. Chem., Oct. 1912.

\section{F. W. Steers.}

Detarring of Illuminating Gas. American Gas Institute-Nov. 1914. 
H. D. Egbert.

Discussion, American Gas Institute-Nov. 1914.

P. E. Landolt.

Discussion and Demonstration, Amer. Electrochem. Soc. Annual Meeting. Oct. 1914.

Arthur T. Beazeley.

Dehydration of Crude Petroleum, a New Electric Process. The Oil Age (Los Angeles) vol. 3, pp. 2-4-April 21, 1911.

W. W. Strong.

"The Positive and Negative Corona and Electrical Precipitation." Trans. Am. Inst. Elect. Eng. Vol. 32, pp. 1305-1314, June 1913. " Electrical Precipitation of Suspended Matter in Gases." Journal Franklin Institute vol. 174, pp 239-263-Sept. 1912. "The Theory of the Renewal of Suspended Matter from Gases." Journal Indust. \& Eng. Chem. Vol. 5, pp 858-860-Oct. 1913.

A. F. White.

"The Electrical Separation. of Tar from Coal Gas." Proceedings of the Michigan Gas Association, 1912. The American Gas Light Journal. Sept. 21, 1914. Vol. 101, No. 12., pp. 177-180.

Philip S. Taylor.

Electric Precipitation of Cement Dust. Jour. Elect. Power and Gas (Los Angeles) March 14, 1914.

General Articles.

Engineering and Mining Journal, vol. 86, (1908) pages 375-377, Cottrell Process for Condensing Smelter Fumes. Vol. 93, (1912). page 44. Metallurgy of Lead in 1911, H. O. Hoffman. Vol. 96 (1913) page 247, Recent Cottrell Electric Precipitation Results. Vol. 97,(1914) page 1107, The Research Corporation and the Cottrell Process. Vol. 98, (1914) page 653, The Cottrell Plant at Garfield, Utah. Vol. 98, (1914) page 873. Electrostatic Fume Precipitation at Anaconda. Metallurgical \& Chemical Engineering, Vol. XIII-No. 2, (1915).

W. H. Howard.

Electrical Fume Precipitation at Garfield. Amer. Inst. Mining Eng. Aug. 11, 1914.

E. M. Dunn.

Discussion, Amer. Inst. Mining Eng. Nov. 1914, page 2738. 